\title{
Adapting wildland fire governance to climate change in Alaska
}

\author{
$\underline{\text { Tait } K \text {. Rutherford }}^{1}$ and Courtney A. Schultz ${ }^{1}$
}

\begin{abstract}
We use concepts drawn from the adaptive governance literature to examine challenges and opportunities for fire management in Alaska, where rising average summer temperatures over the past several decades are associated with statewide increases in wildland fire activity. Alaska's unique interagency fire management structure, rapidly changing climate, and natural resource dependent communities provide a valuable context for study. Our research sought to understand (1) current and future fire management challenges and responses to those challenges; (2) governance structures and processes that act as enablers of and barriers to changes in management approaches; and (3) the institutionalization of new practices. We explored these questions in a qualitative analysis of 41 interviews with fire managers. Participants perceived protection of communities, enhancement of subsistence hunting opportunities, and protection of remote points on the landscape as the most pressing current management challenges, with protection of ecosystem carbon sinks as a possible future challenge. Interviewees identified existing bridging organizations and boundary-spanning work as enabling factors in the governance system. At the same time, they indicated that federal agency budgeting processes, prescriptive laws that mandate the protection of certain values, and divisions across fire and land management personnel and planning processes can inhibit effective responses to management challenges. We found evidence of several types of institutional changes, some underway, and some perceived as necessary in the future. Our research suggests that in a thick institutional context, existing institutions that serve to bridge across actors likely can be repurposed to meet new challenges, while more prescriptive institutions may be less adaptive to changing conditions. This work provides an empirical investigation of adaptive governance in a rapidly changing system and contributes to theory building on institutionalization by shedding light on the nuances and complexities of institutional work.
\end{abstract}

Key Words: adaptive governance; Alaska; climate change; institutional work; institutionalization; public lands management; wildland fire

\section{INTRODUCTION}

Global climatic changes are driving a need to reevaluate and improve environmental governance approaches (Cosens et al. 2014). The concept of adaptive governance synthesizes knowledge from multiple areas of scholarship to inform understanding of the governance of linked social and ecological systems (social-ecological systems) in the face of uncertainty and rapid change (Dietz et al. 2003, Folke et al. 2005). In this study, we sought to understand governance challenges and opportunities in fire management in Alaska, particularly in light of the effects of climate change. Fire regimes in Alaska are closely tied to large-scale climate patterns, and relatively rapid increases in area burned and fire frequency have occurred in the boreal forest and tundra regions of the state in recent decades (Duffy et al. 2005, Kasischke et al. 2010). These changes, an anticipated continuation of these rapid increases going forward, and the associated impacts to natural resource-dependent communities across Alaska make the area an early example of the effects of climate change on a fire governance system. We drew upon the adaptive governance literature to understand the emergence of new governance approaches and processes of institutionalization in Alaska as fire managers respond and adapt to new challenges and conditions (Chaffin and Gunderson 2016). We offer this work as further empirical application of adaptive governance concepts and theories, which allowed us to gain greater insight into current governance opportunities and challenges in Alaska fire management. We also aim to contribute to theory building through the examination of emergent and evolving institutions.

\section{ADAPTIVE GOVERNANCE CONCEPTS AND THEORIES}

The adaptive governance literature builds upon multiple traditions and lines of inquiry (Chaffin et al. 2014). In this paper, we draw from recent literature that considers the collective impact of this work and recognizes adaptive governance as an emergent form of environmental governance that supports collective action, the ability of actors to learn and respond to change, and the evaluation of governance strategies over time (Cosens et al. 2018). We use the term governance to mean the processes of decision making to choose and meet goals regarding the use of a public good (Cosens et al. 2018).

In adaptive governance systems, scholars have observed that multilevel, networked organizational structures are linked with learning and collective action (Wyborn and Bixler 2013, Morrison et al. 2017). In a network, authority is spread across multiple governing levels through nested, diverse, and sometimes redundant organizations that, ideally, are strongly coordinated and collaborative and have a free flow of information (Olsson et al. 2004, Huitema et al. 2009, Koontz et al. 2015). Collaboration and the flow of information through such a network depend on connections both within organizations (Bodin and Crona 2009) and among organizations (Berkes 2009). Specialized groups, including both bridging organizations and boundary organizations, are often integral to successful interorganizational connections. The concept of bridging organizations broadly refers to institutions or bodies that facilitate collective action, deliberation, and transfer of information among actors (Berkes 2009, Crona and Parker 2012). In contrast, the term boundary organization more narrowly describes groups that facilitate coordination between members of different epistemic communities, such as those of science and policy making or management (Cash and Moser 2000, Crona and Parker 2012). Collaboration and connections in a network are requisite for institutional learning processes and collective action, both of 
which are conditions for adaptive governance because they allow for the development and use of knowledge to provide legitimate solutions to governance problems (Folke et al. 2005, Koontz et al. 2015). Several scholars have described case studies in which multilevel networks and associated bridging organizations have been observed as critical components of emerging adaptive governance systems (e.g., Olsson et al. 2004, 2008, DeCaro et al. 2017).

Allowing for improved fit between governing institutions and ecological scales in a complex network is another critical aspect of adaptive governance (Rijke et al. 2012). Different environmental challenges require different spatial coordination of actions, necessitating some scale flexibility and multilevel institutions; in addition, organizations operating at different levels may have comparative advantages with various tasks (Cash and Moser 2000). Because on-the-ground management of ecological units, e.g., plant communities, fisheries, watersheds, firesheds, etc., occurs at local levels, adaptive governance necessitates space for the self-organization of local-level governance networks. Scale-related challenges arise, however, when local governance networks must grapple with climate change and other issues where the scale of the problem and its assessment are distinct from that of management. Scale mismatches, meaning disconnects between the temporal or spatial scales of social organizations and ecosystem processes, are particularly prevalent in wildland fire management in the western United States, where changes in climate and fire regimes are occurring at regional scales, but many decisions regarding budgets, research, land-use, and the designation and prioritization of valued resources occur at the level of individual governments or private entities (Abrams et al. 2015). Boundary organizations are particularly important for addressing such scale-related challenges because they facilitate coordination between groups that work at different scales, such as researchers and fire managers (Crona and Parker 2012).

To create space for local-level governance networks within existing hierarchical structures of regional or national bureaucracies, adaptive governance systems require a degree of reflexivity between local collective action and higher level certainty and stability within the governance system (Craig et al. 2017). State-run bureaucracies are entrenched actors in many countries and serve as the framework for democratic accountability, legitimacy, and stability (Huitema et al. 2009, Morrison et al. 2017). Top-down bureaucracies, however, are commonly plagued by rigidity, and coordination with local actors in multilevel systems is critical to allowing the flexibility necessary for the emergence of adaptive governance (Craig et al. 2017). In a multilevel system, the nesting of networks can support collaboration among organizations at local scales within the hierarchical structure of regional or national bureaucracies, allowing for some flexibility to respond to challenges and needs that occur at different spatial levels (Folke et al. 2007, Wyborn and Bixler 2013).

More recent literature on adaptive governance focuses on processes of emergence and institutionalization. Chaffin and Gunderson (2016) explain that adaptive governance emerges often in response to crisis events, after which new governance approaches become institutionalized during periods of greater stability. Institutions are the formal and informal rules that guide actor behavior in a governance system, and practices are institutionalized if they become commonly accepted ways of doing things (Abers and Keck 2013). In the United States, any form of adaptive governance will necessarily emerge among bureaucratic structures and environmental laws that create a series of formal institutions, which collectively emphasize government management of environmental resources and regulation of actor activity in the system (Cosens et al. 2017). This raises an important question as to how new governance activities emerge within a constrained system and how new institutions come to be.

Institutionalization, even in response to national policy changes, is affected by microprocesses at the local scale that may lead to differing practices among locations (Moseley and Charnley 2014). Although many authors have conceptualized institutions as structures that constrain practice, some recent literature takes a more critical perspective on institutionalization, emphasizing the role of agency and noting that a variety of actors engage in "institutional work," or the creation, maintenance, or disruption of institutions to meet emergent needs in environmental governance (Beunen et al. 2017). The result is a process of "creative syncretism," in which actors regularly recombine and reshape the system of institutions in which they work, making institutions less a series of structures and constraints, and more a series of instruments or playing cards that can be played or reshuffled in myriad ways (Berk and Galvan 2009, Moseley and Charnley 2014). Consequently, institutionalization depends on numerous historical, political, economic, and psychological factors, and institutions at different times and places are variably resistant or susceptible to change (Moseley and Charnley 2014). A key aspect of our research was to contribute to the adaptive governance scholarship with a close look at the role of institutions and institutionalization in the governance system for wildland fire in Alaska.

\section{ADAPTIVE GOVERNANCE FOR FIRE IN ALASKA}

Alaska's ecological and social context provides a particularly valuable opportunity to explore adaptation to climate change in fire governance (Brunner and Lynch 2010). Rapid climatic changes at high northern latitudes have caused the intensification of fire regimes across boreal and tundra ecosystems in Alaska since the 1980s (Duffy et al. 2005, Kasischke and Turetsky 2006, Kasischke et al. 2010, Kelly et al. 2013). Likewise, several scholars have used climate models to project future increases in fire activity over at least the next few decades. Temperature is the strongest determinant of fire occurrence in Alaska, and future increases in fire frequency will likely occur as climate change causes exceedance of certain temperature thresholds (Young et al. 2017). Warming average temperatures will also likely increase the average dryness of fuels in boreal ecosystems regardless of changes in precipitation, causing a heightened probability of large fire events (Flannigan et al. 2016). Climate projections for Alaska have predicted increases in statewide average annual fire frequency, area burned, and fire season length during the first half of the 21st century (Mann et al. 2012, Rupp et al. 2016). These projected future increases in fire activity will likely exacerbate the costs of fire management or, alternatively, leave managers in a position where they are no longer able to maintain fire management activities at current levels (Melvin et al. 2017). 
Numerous authors have explored the implications of these past and potential future changes for social-ecological systems in Alaska. Alaska's isolated and diverse communities are vulnerable to the rapid climatic changes occurring in the region because of their reliance on natural resources for subsistence use (Kasischke et al. 2010, Knapp and Trainor 2015). In combination with climate change, high severity and high frequency fires in the boreal forest can cause lasting shifts toward more early-seral vegetation, and some regions may experience relatively permanent transitions between forested and grassland states (Johnstone et al. 2010, Scheffer et al. 2012, Alexander and Mack 2017). Declines in age class diversity of dominant vegetation with increased burning will likely alter the availability of food for subsistence species such as caribou (Rangifer tarandus) and moose (Alces alces; Jandt et al. 2008, Joly et al. 2012, Mann et al. 2012). Elevated greenhouse gas emissions caused by greater fire activity present another challenge, as carbon release from melted permafrost in tundra ecosystems may cause a substantial positive feedback to the global atmospheric greenhouse gas effect (Schuur et al. 2008, Mack et al. 2011, Pastick et al. 2017). Melting permafrost has also contributed to increased subsidence of land in the tundra, creating an additional positive feedback to carbon release (Jones et al. 2015).

In response to these challenges, prior studies have examined climate change vulnerabilities in Alaskan communities and identified potential adaptations in fire management approaches at the community and statewide scales (Chapin et al. 2008, Trainor et al. 2009). Climate change projections show that the number of days that support fire intensities that exceed suppression capabilities will become more frequent in the boreal forest, rendering suppression infeasible at times, regardless of the availability of suppression resources (Wotton et al. 2017). Recent literature has shown that creating breaks in the most flammable boreal fuel types can aid suppression and reduce risk to valued resources; consequently, the use of fuel management by both Alaska's land and fire management agencies has grown (Beverly 2017, Melvin et al. 2018). Fuel reduction treatments, however, do not effectively change area burned or reduce the occurrence of higher intensity fires when assessed at large spatial extents (Cary et al. 2017). In general, fire management agencies across the United States are facing similar challenges and will likely need to shift management focus away from suppression to a diversity of management tools that directly address the reduction of risk to values and support both social and ecological resilience (North et al. 2012, Calkin et al. 2015, Schoennagel et al. 2017). Existing evaluations of the need for adaptation to climate change in management in Alaska have suggested the need for risk mitigation on private properties, changes to the initial attack prioritization system, and community organization and cross-boundary collaboration for increased fuel management (Chapin et al. 2008, Trainor et al. 2009).

\section{BACKGROUND: FIRE MANAGEMENT ORGANIZATIONS AND INSTITUTIONS IN ALASKA}

A unique set of fire management organizations and institutions is in place to address the complex social and ecological context of fire management in Alaska (Chapin et al. 2008). The organizations involved in fire governance in Alaska include local governments, Alaska Native organizations, and federal and state land and wildlife management agencies. Three specialized "protection agencies" are responsible for fire suppression on all public and private lands in Alaska. These protection agencies work in coordination with federal and state land managers and Alaska Native organizations, collectively called "jurisdictional agencies" (see Fig. 1). The protection agencies are the U.S. Department of the Interior Bureau of Land Management (BLM) Alaska Fire Service (AFS), the U.S. Department of Agriculture Forest Service (USFS), and the Alaska Department of Natural Resources Division of Forestry (DOF). The AFS and the DOF manage fire in several cross-jurisdictional protection units, while the USFS manages fire primarily on USFS lands (AWFCG 2017; see Fig. 2). The protection agencies are separate from the jurisdictional agencies because, in the 1960s and beyond, newly designated federal management units generally elected to use existing BLM or DOF infrastructure for fire suppression (Hull and Leask 2000, Todd and Jewkes 2006). This allowed for operational coordination on remote and cross-jurisdictional fires in a large state with relatively few fire management staff (Todd and Jewkes 2006).

This organizational structure shaped current statewide fire governance institutions. In the late 1990s, to simplify translation of land management goals to the protection agencies, the agencies wrote a consolidated Alaska Interagency Wildland Fire Management Plan (AIWFMP) for unified operational direction. In 2010, the agencies also combined prior bilateral interagency contracts into a single Alaska Master Cooperative Wildland Fire Management and Stafford Act Agreement (Master Agreement; USDOI BIA et al. 2016). The agencies delegate representatives to a committee that coordinates interagency meetings and planning, called the Alaska Wildland Fire Coordinating Group (AWFCG 2017; see Fig. 1).

The AIWFMP outlines an initial attack plan that classifies the entire state into four levels of priority for suppression, called management options, including "critical," "full," "modified," and "limited" (see Table 1). The jurisdictional agencies, with consultation from the protection agencies, prioritize values under these options from "critical" for the highest priority areas for suppression, down to "limited" for areas where the agencies will let fires burn unless they threaten higher priority sites (AWFCG 2017).

The Alaska Native Claims Settlement Act of 1971 (ANCSA) and the Alaska National Interest Lands Conservation Act of 1980 (ANILCA) also shape fire policy. The ANCSA created the Alaska Native Corporations and stipulates that the federal government must sponsor fire suppression on all Alaska Native Corporation and Native allotment land conveyed under the ANCSA (43 USC 1620(e)). The ANILCA mandates that use of federal public lands should have as little impact as possible on subsistence use by rural Alaskans, indicating that the agencies must take into account subsistence hunting, gathering, and timber use values when designating fire management options (16 USC 3112(1)).

\section{RESEARCH OBJECTIVES AND METHODS}

This research was part of a larger project funded by the Joint Fire Science Program (JFSP) to integrate fire and climate modeling with fire manager interviews and workshops to understand how the Alaska fire management community anticipates responding to changes in fire activity as the climate changes. Regarding positionality, we note that, as a funded JFSP project working with 
Fig. 1. Alaska Wildland Fire Governance System Structure. Boxes represent organizations, agencies, and stakeholders involved in wildland fire governance in Alaska (AWFCG 2017). The outermost dotted line encloses all these actors, and thus represents what we call the "Alaska wildland fire governance system" in general. Bridging organizations, regional and local level collaborative groups, and multilevel networks, as we describe in our results and discussion, occur within this broader governance system. The inner dotted lines enclose the two primary statewide bridging organizations, the Alaska Wildland Fire Coordinating Group and the Alaska Master Cooperative Wildland Fire Management and Stafford Act Agreement (i.e., "Master Agreement").

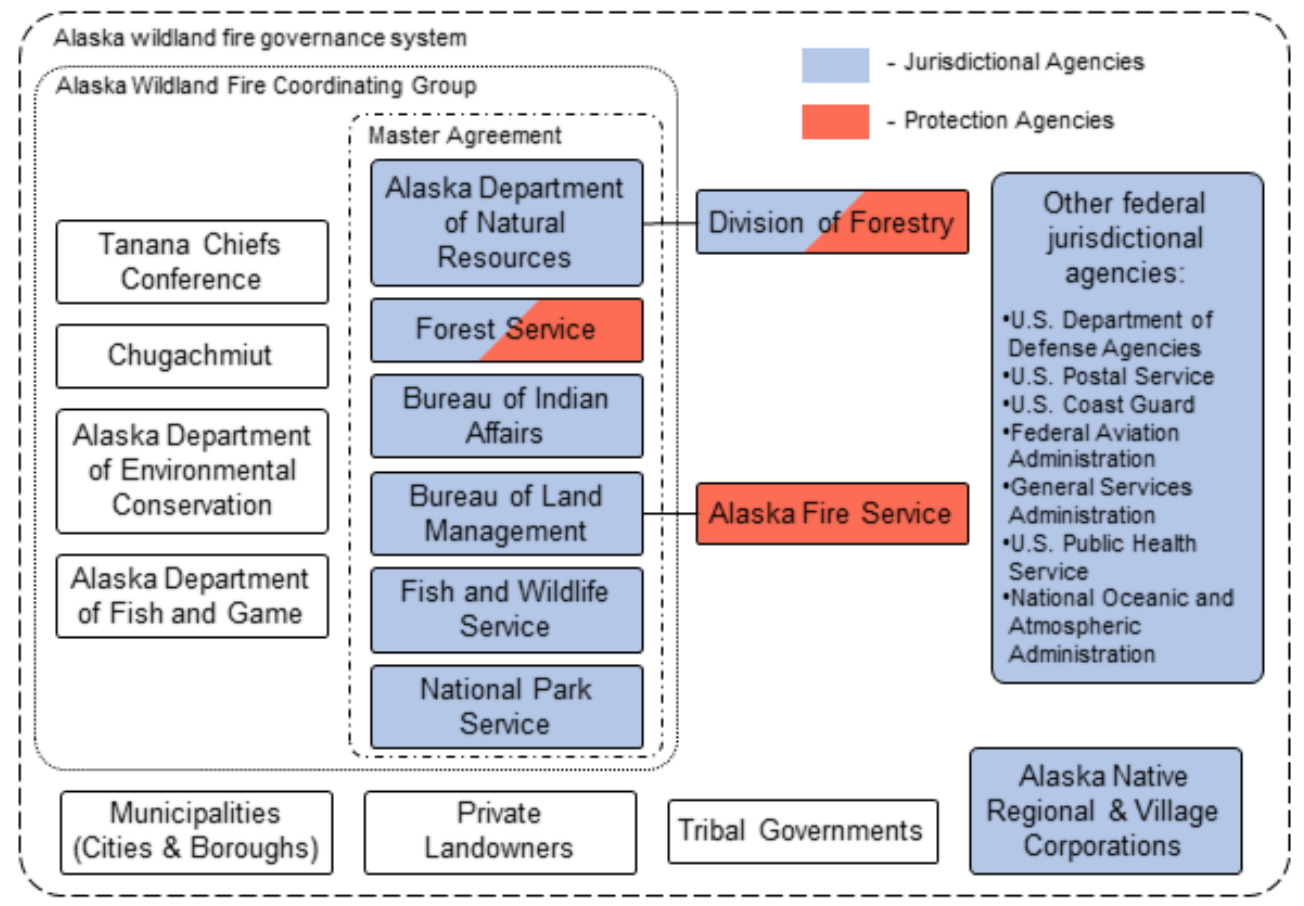

Fig. 2. Map of Protection Agency Zones. Shaded sections in the map represent areas of suppression responsibility for the U.S. Department of the Interior Bureau of Land Management Alaska Fire Service, Alaska Department of Natural Resources Division of Forestry, and U.S. Department of Agriculture Forest Service. Lines within shaded sections delineate administrative divisions for each protection agency.

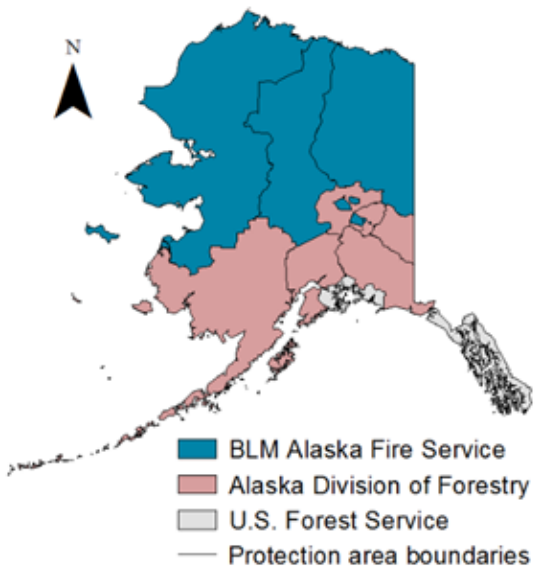

the Alaska Fire Science Consortium (AFSC), we were operating as actors conducting research within the Alaska fire governance system through existing bridging organizations. For this paper, we focus on three research questions based on our interviews with managers. First, we ask: What are the primary challenges and responses managers envision as they adapt to climate change? We recognize that much has been written on this, and our effort here is simply to update existing knowledge as needed (e.g., Chapin et al. 2008, Trainor et al. 2009). Second, we build upon this existing work by asking: What governance institutions do managers think will support or impede necessary activities going forward? Third, we ask: What types of institutional work are managers undertaking or envisioning?

Our data collection consisted of interviews with the primary land and fire managers working in the Alaska fire governance system; thus, our work provides only the perspectives of these actors rather than the entirety of the governance system. We purposively sampled from contact lists provided by the AFSC. These contact lists included fire managers and other fire management agency staff who have recently attended AFSC presentations and meetings or have elected to receive AFSC communications for any reason. Purposive sampling is a qualitative sampling method by which researchers intend to recruit participants who are most likely able to contribute to the answering of research questions 
Table 1. Fire management options (AWFCG 2017).

\begin{tabular}{|c|c|c|c|}
\hline Management option & Default initial action & Priority & Values \\
\hline Critical & $\begin{array}{l}\text { Deploy resources to protect sites and } \\
\text { suppress fires immediately }\end{array}$ & $\begin{array}{l}\text { Contain fires at the smallest acreage } \\
\text { possible }\end{array}$ & $\begin{array}{l}\text { Wildland-urban interface; inhabited } \\
\text { property; critical infrastructure; National } \\
\text { Historic Landmarks }\end{array}$ \\
\hline Full & $\begin{array}{l}\text { Deploy resources to protect sites and } \\
\text { suppress fires immediately (given } \\
\text { resources are not needed to protect areas } \\
\text { in critical option) }\end{array}$ & $\begin{array}{l}\text { Contain fires at the smallest acreage } \\
\text { possible }\end{array}$ & $\begin{array}{l}\text { Cultural sites; recreation areas; remote } \\
\text { structures; high-value natural resources; } \\
\text { any other structures or high-value areas } \\
\text { not in critical option }\end{array}$ \\
\hline Modified & $\begin{array}{l}\text { Same as "full" before a predetermined } \\
\text { date (usually after peak fire season); same } \\
\text { as "limited" thereafter }\end{array}$ & $\begin{array}{l}\text { Same as "full" before a predetermined } \\
\text { date (usually after peak fire season); } \\
\text { same as "limited" thereafter }\end{array}$ & $\begin{array}{l}\text { Suppression buffer zones adjacent to full } \\
\text { or critical; low-priority valued natural } \\
\text { resources (e.g., caribou winter habitat) }\end{array}$ \\
\hline Limited & $\begin{array}{l}\text { Surveillance and small, remote site } \\
\text { ("point") protection }\end{array}$ & $\begin{array}{l}\text { Allow fires to burn to the extent } \\
\text { possible to support natural ecological } \\
\text { processes }\end{array}$ & $\begin{array}{l}\text { Large-scale landscapes with low densities } \\
\text { of values }\end{array}$ \\
\hline
\end{tabular}

(Patton 2015). We prioritized our recruiting of participants from the AFSC lists based on knowledge provided by our collaborators at the AFSC, who were familiar with managers who would be able to provide diverse and informative perspectives. As part of our prioritization, we recruited individuals from as diverse a set of organizations and set of roles and responsibilities as possible within the overarching criterion that they participate in decision making regarding fire management in Alaska. Although we were able to interview individuals from nearly all organizations represented on the AFSC lists, some organizations had greater representation than others because of their higher volumes of fire management staff. We interviewed individuals from the following organizations (we omit some specifics to maintain participant confidentiality): the Alaska Department of Natural Resources Division of Forestry; Alaska Native organizations; borough emergency services departments; other state-level agencies involved in the management of land and the environment; the U. S. Department of Agriculture Forest Service (USFS); the USFS State and Private Forestry; the U.S. Department of Defense military bases' fire operations sections; the U.S. Department of the Interior (DOI) Bureau of Indian Affairs; the DOI Bureau of Land Management (BLM); the BLM Alaska Fire Service; the DOI Fish and Wildlife Service; and the DOI National Park Service. We recruited some interviewees additional to the initial AFSC lists using snowball sampling, meaning we contacted further prospective participants based on recommendations by prior interviewees (Patton 2015). By sampling across types of actors within every organization involved in fire management in Alaska, we intended to reach saturation of information within the scope of our research questions and sample. Ongoing analysis of our data during the data collection process allowed us to determine that additional interviews past approximately $35 \mathrm{did}$ not generate new themes or insights and that we could assume that we had reached a reasonable degree of saturation (O'Reilly and Parker 2013). We recognize, however, that additional interviewees may have provided some additional details or nuances. In addition, broader sampling would be needed to gain a deeper understanding of the perspectives of private citizens, members of Native tribes, and community-based organizations. Throughout the participant sampling and data collection processes, we adhered to protocol approved by our Institutional Review Board to maintain participant confidentiality.
We conducted and recorded 41 semistructured, hour-long interviews. We conducted our interviews using an interview protocol that consisted of a set of open-ended questions that allowed interviews to flow conversationally and participants to fully articulate ideas from their own perspectives (Yin 2016). Our interview protocol asked about four major topics: (1) current priorities and challenges in fire management; (2) potential future fire management strategies and approaches; (3) needed policy or planning changes to address challenges; and (4) general science needs and feedback regarding our fire and climate model projections. Not all the questions we asked necessarily informed our research questions for this paper, which stem from themes specific to adaptive governance that we identified during our data analysis. We recorded and transcribed each interview.

Our data analysis process was a thematic analysis, which is a method for identifying, interpreting, and reporting patterns in qualitative data (Braun and Clarke 2006). We carried out the thematic analysis using qualitative coding and memoing techniques (Yin 2016). We began by coding each interview using the online software Dedoose to organize our data according to themes, or common patterns or ideas related to our research questions (Braun and Clarke 2006). Some of these themes derived from the practical questions in our interview protocol (e.g., challenges, priorities, future management strategies or tactics, needed changes in policy or planning, etc.) because of the practical nature of our overarching research objective as a JFSPfunded project. Other themes we identified during the coding process (e.g., interorganizational relationships, communication between epistemic communities, issues related to governing level and scale, etc.) derived from our positionality as scholars of public policy and environmental governance. Throughout the coding process, we wrote memos to iteratively collect our interpretations of the data and develop an understanding of the thematic relationships among the excerpts. This memoing process allowed us to inductively identify new, emergent themes. Once we had fully organized our data excerpts, we referenced all these themes using potential explanatory concepts in the public policy and environmental governance literatures. Among these literatures, we found themes in the adaptive governance literature to be most explanatory of the themes we identified during our coding and memoing process. We then returned to our excerpts to reassess them in relation to concepts in the adaptive governance literature 
(e.g., bridging organizations, multilevel approaches, scale-fit, networks, institutional barriers, institutional emergence and change, etc.) and gain deeper insight into how our data related to these concepts. To analyze our excerpts according to adaptive governance themes, we wrote a further set of memos regarding the relationships between our data and the adaptive governance themes.

In our results, we report the range of themes discussed in interviews that relate to adaptive governance. We have aggregated these into three overarching topics. Although interviewees sometimes had differing emphases in response to our questions, they seldom expressed opposing perspectives. In the results, we note any opposing viewpoints or instances when participants gave alternative suggestions for governance solutions.

\section{RESULTS AND DISCUSSION}

We address each of our research questions in turn and present a subset of our data for illustrative purposes; fuller versions of those excerpts and additional excerpts can be found in our supplemental appendix (Appendix 1). We have organized our findings in the subsections for each of our primary research questions, with a presentation of themes generally from most to least common. For ease of interpretation, we provide some discussion of our findings in this section, leaving our conclusions and connections to the broader literature for the closing section.

\section{Management challenges and needed responses}

Participants consistently mentioned that increases in fire activity are causing major management challenges, as we would expect based on previous work. These increases strain the system's finite suppression capacity during large fire years and elevate risk to some valued resources (see Appendix 1.1). An interviewee said that managers have a "sense of nervousness as far as not being able to handle this new fire load" (see Appendix 1.2). Interviewees identified three primary management challenges related to limited capacity, which have been identified previously by Chapin et al. (2008) and Trainor et al. (2009), indicating their persistence over the past decade. These areas are the following: improving community protection and risk reduction in the wildland-urban interface, i.e., areas of human development that experience elevated wildland fire risk because of their proximity to undeveloped lands; facilitating subsistence use opportunities, primarily through the enhancement of moose and caribou habitat; and exploring ways to improve policy or management tools for the protection of remote or undeveloped Native allotments and remote private cabins (see Table 2). The frequency of discussion of these issues during our data collection indicated that these have become a common focus in the fire management community. Our interviewees additionally discussed the nascent consideration in the fire management community of the potential use of fire management to protect ecosystem carbon sinks in permafrost or timber (see Table 2). Though the loss of permafrost carbon sinks due to wildland fire has drawn attention in the literature for over a decade, climate change mitigation via fire management is a relatively new topic in discussions among the fire management agencies in Alaska.

With each of these current and potential priorities, participants discussed associated management approaches. Participants identified continued suppression, the creation of large-scale fuel breaks, and increased preparedness measures as approaches to
Table 2. Current key priorities for Alaska fire management identified by participants.

\begin{tabular}{|c|c|}
\hline Management priority & Possible approaches going forward \\
\hline $\begin{array}{l}\text { Risk reduction and } \\
\text { protection of } \\
\text { communities in the } \\
\text { wildland-urban interface }\end{array}$ & $\begin{array}{l}\text { Expansion of "critical" and "full" protection } \\
\text { buffers around communities; creation of } \\
\text { large-scale breaks in flammable fuels around } \\
\text { communities to aid suppression; community } \\
\text { preparedness, including defensible space }\end{array}$ \\
\hline $\begin{array}{l}\text { Ensuring the availability } \\
\text { of subsistence values, } \\
\text { including moose and } \\
\text { caribou habitat }\end{array}$ & $\begin{array}{l}\text { Prescribed fire and fire use to promote early } \\
\text { postfire age classes near communities; initial } \\
\text { attack suppression to protect known caribou } \\
\text { habitat near communities }\end{array}$ \\
\hline $\begin{array}{l}\text { Protection of remote } \\
\text { values, including Native } \\
\text { allotments and } \\
\text { permitted cabins }\end{array}$ & $\begin{array}{l}\text { Identification of all remote sites in the } \\
\text { interagency Known Sites Database; efficient } \\
\text { point protection and risk acceptance } \\
\text { commensurate with the value of the } \\
\text { protected site }\end{array}$ \\
\hline $\begin{array}{l}\text { Carbon sequestration in } \\
\text { ecosystem carbon sinks, } \\
\text { including permafrost } \\
\text { and timber (potential } \\
\text { priority) }\end{array}$ & $\begin{array}{l}\text { Initial attack suppression to protect identified } \\
\text { high-priority ecosystem carbon sinks }\end{array}$ \\
\hline
\end{tabular}

ensure protection and risk reduction for communities in the wildland-urban interface. Where managers anticipate an increase in fire danger and the likelihood of large fires moving quickly across the landscape because of the continuity, warming, and drying of fuels, some participants saw the need to expand "critical" and "full" initial attack suppression areas around communities to "accommodate the additional frequency and potential size" of future fires (see Appendix 1.3). In addition, many participants emphasized the benefits of large-scale fuel breaks near communities to aid suppression. Some interviewees indicated their "frustration" with the relatively small amounts of funding for fuel management in Alaska, saying fuel reduction "funding has ... been leaner and leaner" (see Appendix 1.4-6). Participants also frequently discussed the need for community preparedness through the creation of defensible space around homes and the use of nonflammable building materials, which can strengthen "the integrity of the community from a fire resilience standpoint" (see Appendix 1.7-8). As an example of successful implementation of these needs, many participants talked extensively about a formal collaborative group called the Kenai Peninsula All Lands/All Hands group, which uses crossboundary pooling of resources to implement large-scale, crossjurisdictional fuel breaks around communities. Two of the group's fuel breaks have proven instrumental in mitigating the effects of two large fires on the peninsula (see Appendix 1.9). Beyond the implementation of fuel breaks, an interviewee described the collaborative group as a forum for diverse organizations to "talk about how [they] can help each other achieve ultimately very similar objectives" (see Appendix 1.10). The collaborative group has also engaged in public outreach and education regarding defensible space and the fireproofing of structures (see Appendix 1.11). A few participants said that the agencies are promoting similar collaborative efforts in other areas of the state but that such arrangements are only possible in the most densely populated regions, where organizations and communities share landscape and fire management challenges (see Appendix 1.12). 
Regarding subsistence use opportunities, participants indicated that the maintenance of wildlife habitat will require both using fire to meet resource objectives and fire suppression to support a diversity of age classes and forest cover types on the landscape within the hunting ranges of rural Alaskan communities. Some participants said that they would like to see an increase in fire on the landscape to promote early seral moose habitat near communities, either through broadcast burning, i.e., prescribed fire, or management of natural ignitions (see Appendix 1.13). To reconcile the need for fire on the landscape with the goal of community risk reduction, interviewees again explained the need for fuel breaks around communities to increase decision space for fire management officers and to give them "the ability to manage a fire for multiple objectives," rather than immediately putting it out (see Appendix 1.14). For caribou, on the other hand, many participants indicated concern among many fire managers about declining caribou hunting opportunities because of increased burning of caribou winter forage lichens in certain areas (see Appendix 1.15). Participants said that some jurisdictional agency units have moved areas of tundra and old-growth black spruce (Picea mariana) in which the lichens grow into the "modified" management option near communities traditionally dependent on caribou hunting; by doing so, the jurisdictional agencies intend to improve "the sense of well-being that native subsistence hunters have when they're out on the landscape" (see Appendix 1.16-17). This action has designated large swaths of land as priority for initial attack to suppress fires for roughly the first half of the fire season. An interviewee indicated that this management option change was "fairly controversial" because many managers wanted to allow the continuation of natural processes (see Appendix 1.16). In summary, the issue of subsistence hunting has resulted in shifts toward both more suppression and more fire use, depending on locally specific needs for wildlife habitat.

To protect remote points on the landscape including Native allotments and private cabins, participants suggested the need for both improved data and more efficient point protection tactics. In the planning process, many interviewees indicated that the interagency database of small points on the landscape, called the Known Sites Database, is not complete, making it difficult for the protection agencies to know what action to take on remote fires. An interviewee also related that the protection agencies must "be constantly checking with the jurisdictional agency and the land management agency about their position on whether they want [a] cabin protected or not, because their policies change over time" (see Appendix 1.18). In addition, some participants acknowledged that point protection is often not efficient because of aversion to risk of property damage among fire management officers (see Appendix 1.19). Participants said that some managers place suppression resources on point protection for long periods of time, when quick burnout methods could be more efficient and more commensurate with the value of the protected point (see Appendix 1.20).

The final major issue identified by participants was the protection of carbon sinks. Participants said that this is not currently an actionable priority for the agencies, but that recent research on carbon emissions from permafrost and the sale of timber as carbon offset credits in the California carbon market by some Alaska Native Claims Settlement Act (ANCSA) Native Corporations has generated "background talk" among managers regarding the potential need to mitigate greenhouse gas emissions from ecosystem carbon sinks (see Appendix 1.21-22). Participants explained that this would require a significant suppression effort in tandem with constant monitoring of the location of and risk to permafrost. One person explained that even if the agencies were to implement a policy to protect permafrost, management “wouldn't change as much as [one] would expect, because it's not likely [the agencies would] get ... more resources or money to put all those fires out" (see Appendix 1.23).

\section{Adaptive structures and processes}

Our next research question focused on what aspects of the governance system managers identified as supportive or problematic as they address current fire management challenges. Participants emphasized that formal and informal face-to-face interactions, both in biannual meetings and as a result of the concentration of fire management offices in Anchorage and Fairbanks, facilitate relationships critical for fire management. "Working relationships" among the agencies, said an interviewee, are very good because personnel constantly communicate (see Appendix 1.24). Actors from the protection and jurisdictional agencies meet face-to-face biannually in pre- and postseason interagency meetings in Fairbanks. Interviewees said that these spring and fall meetings allow actors to "talk when things aren't on fire" and resolve issues as a group (see Appendix 1.25-26). Participants noted that formal documentation systems also provide a baseline for effective communication by keeping actors aware of updates to planning and decisions. These systems, such as the Alaska Interagency Wildland Fire Management Plan (AIWFMP) and the Known Sites Database, are regularly reviewed and refined to improve communication (see Appendix 1.27-28). In collaborative groups, such as the Kenai All Lands/ All Hands group, which works at a regional level, i.e., the Kenai Peninsula, to plan fuel treatments, connections exist across governing levels, from the state and federal agencies to the local borough governments to the public (see Appendix 1.29). In the biannual meetings, connections span types of actors, from land managers to fire managers at multiple levels and with different responsibilities. Our interpretation of this data is that these formal and informal systems exhibit elements of governance networks at both statewide and more regional scales. The Alaska Wildland Fire Coordinating Group, which oversees the AIWFMP, and the Kenai All Lands/All Hands group act as bridging organizations at the statewide and regional levels by coordinating communication and action among the actors at those levels and, in the case of the Kenai group, also across levels as part of a multilevel network with support from national and state bureaucracies.

Participants also described a strong relationship between the management and research communities, facilitated by the Alaska Fire Science Consortium (AFSC). Through connections with resources external to this system, the AFSC acts as a boundary organization to facilitate the flow of information between research and management. According to participants, the AFSC is helpful to managers because of a process in which the managers communicate their research needs annually to the AFSC, which then hosts presentations on current science and connects managers to researchers and new scientific information throughout the year (see Appendix 1.30-32). An interviewee talked about the importance of "having a robust fire science" 
program involved in fire management to improve agencies' capacity to respond to uncertainty under climate change (see Appendix 1.33). Participants often indicated that managers integrate relevant research into management considerations whenever appropriate. Current discussions regarding caribou and moose habitat enhancement and the prevention of large-scale permafrost melt stemmed from attention to those issues within the scientific community after several large fire incidents in the 2000s (see Appendix 1.34). Interviewees also often said they are actively seeking information regarding the effectiveness of fuel breaks to be able to adapt them to changing conditions and community needs (see Appendix 1.35). The awareness of current science has allowed managers to understand both new priorities and the appropriate approaches to those needs. For example, participants frequently referred to the need to adapt fire management to a changing climate. One interviewee said that "the effects of climate change ... [are] definitely something that's taken very seriously [in Alaska]" (see Appendix 1.36). This attention to science has spurred discussions within the fire management community about their anticipated capacity limitations and future priorities, and the need to foster local collaboration and integrate land and fire management to improve climate change adaptation outcomes. Based on interviewee comments, the AFSC has played a key role in spanning the boundary between researchers and managers.

Our interviews also revealed challenges stemming from current governance structures and processes. Some participants described issues with budget requests and prioritization of funding. An interviewee explained that state legislators meet with fire managers "to understand what [the fire management agencies] do, [and] how [they] do it," and lawmakers "have been very supportive of the fire program ... but not to the point that it's been a priority for them legislatively or budgetarily [sic]" (see Appendix 1.37). According to a few participants, it is the state legislature's preference to fund fire suppression using supplemental funding to avoid increasing up-front budget appropriations. Some interviewees mentioned that national-level Department of the Interior (DOI) budgeting models allocate funds based on metrics of suppression priorities in the conterminous United States, such as minimization of area burned (see Appendix 1.38). These metrics do not apply well to suppression strategies in Alaska, which focus heavily on the protection of small points within areas where the agencies will otherwise let fires burn (see Appendix 1.39). Participants indicated that fire managers in Alaska are communicating to national agency leadership that Alaska requires a unique budgeting process because current national budgeting models have not allocated enough funding for the agencies to protect all valued resources during recent large fire years. These problems stem from scale-related mismatches. Federal and state agencies face a persistent temporal scaling challenge in budgeting for suppression capacity because legislatures often respond to fire funding needs reactively and annually, whereas sustained resource investments could extend the purview of choices about prioritization of resources for suppression and fuel treatment. Fitting Alaska into DOI national budgeting systems has created a significant spatial scale mismatch. The national budgeting system is designed primarily for the conterminous 48 states, where management units are organized at smaller spatial extents and characterized by different patterns of land use than in Alaska.
A second persistent issue mentioned by participants was the existing agency policies regarding prioritization of the protection of remote private properties, such as remote cabins and Native allotments, which demands significant suppression resources (see Appendix 1.40). Allotment protection policy, in particular, is prescriptive and allows little flexibility in resource prioritization, according to participants (see Appendix 1.41). A few interviewees expressed a sentiment that allotment protection has generated some controversy in the fire management community (see Appendix 1.42). We found, however, that our interviewees across positions and agencies generally supported the protection of allotments while expressing a desire for greater flexibility in prioritizing them against other values for initial attack or for allowing fire to burn on allotments when that might be desirable to allotment owners (see Appendix 1.40, 1.43). An interviewee indicated a preference to "balance the need and availability of resources to [suppress fire on or near allotments] versus the protection of these other things that are out there being threatened" (see Appendix 1.43). We suggest that allotment policy is another scale-fit issue, because the protection of small plots of land does not match the statewide scale of resource mobilization or the landscape scale of many boreal and tundra fires.

Our interviewees identified several other issues related to the fit of governance scales and the need for additional bridging work among agencies. Participants emphasized that the fundamental organizational division between the jurisdictional and protection agencies makes it difficult for the protection agencies to meet land management goals and identify values during extended attack situations and especially during large fire years. An interviewee explained this challenge (see Appendix 1.44):

\section{[The protection agency fire management officers], as that fire gets larger, [have] to make sure that they have continued to recognize that these additional jurisdictions have possible values that are threatened, and that can be difficult if you've got a lot of fire on the landscape, just keeping track of every one of them and making sure that all the jurisdictions are appropriately notified.}

Participants said that this divide makes detailed, preloaded information in the Wildland Fire Decision Support System (WFDSS) and good working relationships among fire management officers critical in Alaska (see Appendix 1.45-46). Many participants also described a problematic compartmentalization of land and fire management responsibilities among agency administrators (i.e., line officers), resource advisory staff, and fire management officers within the jurisdictional agencies (see Appendix 1.47-48). This divide, which occurs internally within agency units, inhibits the identification of fire management approaches that would benefit resources. With increasing fire activity across the landscape, participants said that jurisdictional agency administrators need to clarify for fire managers in both the jurisdictional and protection agencies the desired ecosystem conditions that might be threatened by future fire (see Appendix 1.49). An interviewee also described a need for "the agency administrators ... to learn some of the challenges [of fire management] and incorporate that into some of their wildland fire decision making" (see Appendix 1.48). Some participants mentioned that better communication between jurisdictional agency administrators and protection agency fire managers might help move protection agency culture toward a greater risk 
acceptance regarding burning near valued resources (see Appendix 1.50). This integration of land and fire management would require a shift in "personalities, and perspectives, and culture" both among and within agencies (see Appendix 1.51). An alternative change suggested by a few interviewees entails the shift of prescribed fire and fuel treatment responsibilities to the jurisdictional agencies (see Appendix 1.52). This would leave the protection agencies to remain focused on suppression and risk reduction. Interviewees disagreed in their suggested pathways, whether they were improved communication between jurisdictional and protection agency staffs or a shifting of fuel management responsibilities to jurisdictional agencies; nonetheless, interviewees consistently emphasized that greater integration of land and fire management will help agencies in the fire management system better meet objectives by increasing ecosystem resilience to fire.

In essence, the Alaska fire management community recognizes that the increasing presence of fire as a dominant ecological process necessitates greater linkages between fire and land management personnel and processes. This set of challenges regarding the integration of fire and land management planning relates to both scale mismatches and the importance of bridging organizations. There is temporal scale mismatch as land management and fire management planning proceed on different timelines. There are also spatial scale mismatches between fire processes, other ecological variables of interest, and the geographic extent at which different agencies are organized. Our data reflect that individual agencies are not organized at the variety of spatial scales at which ecological processes of interest occur, necessitating bridging structures with some scale flexibility and increased partnerships among agencies and actors working at different scales.

\section{Emergent practices and institutional change}

Finally, we looked for examples of emergent governance approaches and institutional change. The Alaska fire governance system consists of myriad long-standing institutions that developed over time as agencies and units were created in response to new challenges, laws, and land designations. The mismatch in spatial extent between the protection and jurisdictional agencies necessitated the formation of multilevel, bridging institutions, like the AIWFMP, the Master Agreement, and biannual interagency meetings, and other informal norms, including consistent phone communication and face-to-face meetings that allow for necessary coordination. In response to questions about the need for broad changes within the governance system, several interviewees talked about the robustness of the current system (see Appendix 1.53). One interviewee does not expect major changes in the system because the agencies "have a real good model, the Alaska model, and it's pretty solid," and the interviewee indicated that the model works because all the agencies are "working together" (see Appendix 1.54). Participants generally viewed the AIWFMP, the Master Agreement, and the biannual meetings as institutions that will allow them to adapt management strategies to climate change because they support multilevel and cross-actor communication within the governance system (see Appendix 1.25). In the words of an interviewee, the meetings allow communication "a little bit in the springtime [when] you're thinking about what's coming up ahead of you, and in the fall, you're doing a little review of what happened during the season and what issues were there" (see Appendix 1.25). Based on the breadth of comments by interviewees about the importance of communication, interorganizational relationships, and bridging organizations, we suggest that effective coordination and information dissemination through these institutions has helped actors in Alaska to set cohesive priorities, understand new challenges such as climate change, and support new management approaches. These bridging institutions appear to be foundational to the current fire governance system in Alaska.

At the same time, in the face of changing fire regimes, interviewees sometimes mentioned a need for some tweaks to the system's existing bridging institutions (see Appendix 1.55). With challenges spurred by climate change, such as the need for better integration of land and fire management planning, participants explained that the biannual interagency meetings may need to allow for more time for discussions among planners and administrators from both the jurisdictional and protection agencies (see Appendix 1.56-57). Alternatively, participants mentioned the possibility for creating specific forums or a specialized group for interagency planning discussions that would offer additional opportunities for updating management options to rapidly changing ecological conditions (see Appendix 1.58). Such a specialized group, said an interviewee, "would get pretty good at going through the process" of updating the AIWFMP (see Appendix 1.58). These comments by interviewees indicate that fire managers are in the process of envisioning needed institutional work to improve the effectiveness of existing bridging structures and processes.

Although existing bridging institutions are undergoing repurposing in response to the challenges of increasing fire activity, the Kenai Peninsula All Lands/All Hands group is an example of institutional emergence. The collaborative group coalesced in the early 2000 s in response to several large insectrelated mortality events. Existing actors could not provide fuel management at the necessary scale; therefore, at a regional scale, the agencies, Alaska Native organizations, and municipalities came together to address this management challenge. According to interviewees, the emergence of this institution on the Kenai Peninsula was successful because of local circumstances, including the large-scale morality events and the proximity of towns to one another, leadership from within the agencies, and initial top-down funding to address the issue (see Appendix 1.59). Since then, said interviewees, the group has shifted toward implementing "strategic fuel breaks, as opposed to dealing with bark beetles," and has also expanded to assume responsibility for facilitating all interagency and public communication regarding fire on the Kenai Peninsula (see Appendix 1.10). This expansion has resulted from a continued commitment to the All Lands/All Hands group by local agency leaders (see Appendix 1.59). As new fuel management needs on the Peninsula emerge, the members of the collaborative group pool diverse funding sources to complete the needed projects (see Appendix 1.60-61). The All Lands/All Hands group serves as an example of an emergent and enduring regional-scale institution involving agencies organized at several levels. The institution has adapted to changing circumstances as a result of ongoing institutional work by those actors.

More comprehensive changes to institutions were recommended by interviewees regarding the prescriptive requirement to provide 
fire suppression for Native allotments and the formulaic approach to fire budgeting for the federal agencies in Alaska. Regarding allotment protection, a few interviewees mentioned the possible need to reassess the default "full" management option designation for all allotments. One interviewee said, "It's a federal requirement, but it's not achievable, really, and we need to look at doing something different with that" (see Appendix 1.62). According to this same interviewee, some fire management officers have chosen to withhold suppression resources from initial attack for remote allotments in cases when they have expected imminent fire risk to more populated areas because of projected weather (see Appendix 1.63). Another interviewee indicated that collaborative decision making might be an appropriate alternative to prescriptive law (see Appendix 1.43). In addition, while interviewees explained the scale-related issues with fire budgeting for the agencies in Alaska, they indicated that when they have attempted solutions within the existing nationallevel budgeting framework, they have found that budgetary needs for Alaska are "extremely difficult to model, if not impossible, and extremely expensive to do" (see Appendix 1.39). In general, interviewees said that improved communication between the agencies and lawmakers involved in appropriations would be the most useful tool to address the agencies' financial needs (see Appendix 1.64). We observe that these two institutions, allotment policy and budgeting processes, may require substantial revision because they are prescriptive and formulaic and do not allow fire managers the flexibility needed to meet changing fire regimes.

Overall, our results show that participants identified three different types of institutional work occurring or that they believe should occur in Alaska in response to changes in fire regimes, including repurposing existing institutions, emergence of new institutions, and potential formal change to a subset of existing institutions. These show the range of institutional change processes that can occur in the development of adaptive governance.

\section{SYNTHESIS AND CONCLUSIONS}

Our research considers management priorities and governance changes and challenges in Alaska fire management. We present this work both as an empirical application of adaptive governance theories to an applied research project and specific governance context, and as an opportunity to look at the emergence and institutionalization of new governance approaches in Alaska where conditions are changing rapidly with significant implications for managers and communities. Other than a greater emphasis on fire management to maintain carbon sinks, the management challenges we identified have been discussed elsewhere to a large extent (e.g., Chapin et al. 2008, Trainor et al. 2009); therefore, we spend the bulk of this section discussing our findings on adaptive governance processes, structures, and forms of institutional work.

As we explored the governance factors that our participants said acted as facilitators and barriers to success, we identified several variables commonly highlighted in the adaptive governance literature that facilitated interpretation of our findings. For instance, we found that interagency networks are supported by bridging organizations at multiple spatial scales, including the Alaska Wildland Fire Coordinating Group and the Kenai Peninsula All Lands/All Hands collaborative group. Fire management now and into the future will require continued utilization of the existing collaborative networks and bridging organizations at multiple levels of the governance system. There may be a need for additional, regionally focused groups like the Kenai group to undertake the work of fuel management if this becomes a more common need in Alaska fire management, and these likely will need to integrate local, state, and federal agencies as part of a multilevel network. In addition, we found that connections to researchers through the boundary work of the Alaska Fire Science Consortium are critical components of successful fire governance in Alaska. Scholars note that such boundary work is important in a context where the ecosystem and climate change must be assessed at larger spatial extents than those at which individual managers act and at which actors are organized (Cash and Moser 2000, Kleindl et al. 2018). We also heard from managers that some institutions pose problems that arise largely from scale mismatches. For example, there are problems securing adequate annual appropriations for some federal agencies in Alaska, such as the Alaska Fire Service, through the nationwide Department of the Interior and Bureau of Land Management fire budgeting systems, which is perhaps a matter of spatial scale mismatch and the geographic disconnect between Alaska as a large, Arctic state and the contiguous 48 states. There also is some concern about the future ability of fire managers to sustain existing commitments to point protection and the need to overcome divisions between land and fire management planning, which result from both temporal and spatial scale mismatches.

An area of particular interest for us was to examine our data in relation to the emergence and institutionalization of new adaptive governance approaches. We saw evidence of the emergence of new governance approaches at the regional scale with the Kenai All Lands/All Hands group, which has remained in existence for several years. Regarding the reshaping of existing institutions, our evidence indicates that some governance institutions in Alaska are effective but may need updating to better fit the current context of fire management. Current interagency management networks need to do more to bridge the divide between the protection and the jurisdictional agencies to better connect land management planning processes with fire management. This kind of crosssectoral work is essential as ecological disturbances become more common and affect multiple resources and values. Like other areas of public administration, this increased complexity, coupled with a limited capacity for any one agency to solve multifaceted problems, necessitates greater coordination across agencies and with nonstate actors (Kettl 2000). In addition, although individuals noted that existing interagency structures were useful, they said that objects like the Alaska Interagency Wildland Fire Management Plan (AIWFMP) need to be updated through some concerted action beyond current existing, annual processes because of the challenges presented by increased fire activity. At the same time, as we noted above, many interviewees suggested that nationwide budgeting processes and prescriptive suppression policies may no longer be viable for Alaska.

We suggest, based on this work, that actors can repurpose and update existing institutions that allow for bridging across organizations; this is a kind of institutional work and form of creative syncretism, by which actors can shape institutions to serve new circumstances (Berk and Galvan 2009). To recap, the 
AIWFMP and the biannual meetings include mechanisms for regular updates to policy and initial attack planning, allowing for changes in strategies as fire regimes intensify. These were largely put in place to coordinate agencies that had disparate fire management responsibilities and existed to some extent as remnants of previous jurisdictional responsibilities, missions, and interrelationships. Although they were created during a different era of land management concerns, and despite the need for some updating, these interagency bridging forums are proving useful for addressing new challenges. Although these institutional changes may have been prompted by changing conditions and years with relatively large wildfire extent, they are occurring primarily as part of ongoing meetings, planned updates, and established processes in an incremental fashion. In a thick institutional context, many changes may be incremental, and emergent practices may become more quickly viable and institutionalized when they can be nested within the existing context of formal institutions. On the other hand, some institutions in Alaska are more prescriptive and static, and thus may require changes in policy or law. The existing policies that prescribe budget decisions and specific fire management responses may be less adaptive to changing conditions than other institutions in current contexts. If these institutions do not change, actors may choose to ignore formal institutional requirements when they conflict with constant guiding principles in the fire management community, such as firefighter safety or cost-effectiveness in the use of resources. In this case, changing conditions may set the stage for a disconnect between formal institutions and on-the-ground practice.

Our evidence reveals, as the literature on institutional processes suggests, that there is ongoing institutional work taking place in response to change or crisis events. This process of institutionalization is complex, with actors creating, reshaping, and potentially replacing institutions, often in an incremental fashion. Rijke et al. (2012) identified the importance of understanding to what extent existing and potential governance solutions are fit for their purposes. Existing structures that create bridging opportunities may be the type of governance institutions that can be repurposed in the face of ongoing change, while policies that prescribe specific responses from government may be less likely to be adaptive or to be "a good fit" as conditions change. We do not suggest, however, that all prescriptive policies conflict with adaptive governance. Others have noted that regulatory requirements, especially those that set baseline standards of compliance rather than prescribing specific responses to problems, can facilitate adaptive approaches (Cosens et al. 2017). An area for ongoing research is to understand how existing institutions are repurposed, reshaped, replaced, or sometimes evaded as social-ecological systems evolve, and how different emergent institutions may more or less successfully fit within existing contexts.

Lessons drawn from Alaska's experience can be useful for informing broader issues in adaptive governance and fire management. Given the rapidity of change in the Arctic landscape, Alaska is a particularly valuable place to understand the emergence of adaptive governance (Brunner and Lynch 2010, Chapin et al. 2014). The pace of change and its direct effects on social-ecological systems present a distinct opportunity for researchers to observe the effects of governance change over time, which may prove relevant to fire management worldwide as the climate changes (Moritzet al. 2012, Stephens et al. 2013). Alaska's management options map and approach to fuels management may inform approaches in the conterminous United States that will need to allow for more fire (Schoennagel et al. 2017). The challenges of integrating fire and land management planning more effectively and how to prioritize investments and suppression efforts are emerging issues in other parts of the United States (Schultz et al. 2019). More broadly, experiences in Alaska may be useful where others have seen opportunity to expand adaptive governance theory and practice to systems facing an array of natural hazards (Djalante et al. 2011).

Responses to this article can be read online at: http://www.ecologyandsociety.org/issues/responses. $\mathrm{php} / 10810$

\section{Acknowledgments:}

This research was part of a project entitled "Impacts of Climate and Management Options on Wildland Fire Fighting in Alaska: Implications for Operational Costs and Complexity under Future Scenarios," made possible by funding from the Joint Fire Science Program, Project 16-1-01-18, with additional support for TKR from the McIntire-Stennis Cooperative Forestry Program at Colorado State University. We greatly appreciate the insight and ideas derived from numerous reviews and informal discussions with our collaborators, Paul Duffy, Nancy Fresco, and Randi Jandt, and the members of the CSU Public Lands Policy Group. We also thank the Alaska Fire Science Consortium for facilitating our involvement in presentations and workshops in Fairbanks and Anchorage. Finally, we are enormously grateful to the individuals who took the time to interview with us, participate throughout multiple stages of our project, and give us insight into fire management in Alaska.

\section{LITERATURE CITED}

Abers, R. N., and M. E. Keck. 2013. Practical authority: agency and institutional change in Brazilian water politics. Oxford University Press, Oxford, UK. http://dx.doi.org/10.1093/acprof: oso/9780199985265.001.0001

Abrams, J. B., M. Knapp, T. B. Paveglio, A. Ellison, C. Moseley, M. Nielsen-Pincus, and M. S. Carroll. 2015. Re-envisioning community-wildfire relations in the U.S. West as adaptive governance. Ecology and Society 20(3):34. http://dx.doi. org/10.5751/ES-07848-200334

Alaska Wildland Fire Coordinating Group (AWFCG). 2017. Alaska interagency wildland fire management plan 2016. AWFCG, Fairbanks, Alaska, USA. [online] URL: https://fire.ak.blm.gov/ administration/awfcg.php

Alexander, H. D., and M. C. Mack. 2017. Gap regeneration within mature deciduous forests of Interior Alaska: implications for future forest change. Forest Ecology and Management 396:35-43. https://doi.org/10.1016/j.foreco.2017.04.005

Berk, G., and D. Galvan. 2009. How people experience and change institutions: a field guide to creative syncretism. Theory and Society 38(6):543-580. https://doi.org/10.1007/s11186-009-9095-3 
Berkes, F. 2009. Evolution of co-management: role of knowledge generation, bridging organizations and social learning. Journal of Environmental Management 90:1692-1702. https://doi.org/10.1016/ j.jenvman.2008.12.001

Beunen, R., J. Patterson, and K. Van Assche. 2017. Governing for resilience: the role of institutional work. Current Opinion in Environmental Sustainability 28:10-16. http://dx.doi.org/10.1016/ j.cosust.2017.04.010

Beverly, J. L. 2017. Time since prior wildfire affects subsequent fire containment in black spruce. International Journal of Wildland Fire 26(11):919-929. https://doi.org/10.1071/WF17051

Bodin, O., and B. I. Crona. 2009. The role of social networks in natural resource governance: What relational patterns make a difference? Global Environmental Change 19(3):366-374. https:// doi.org/10.1016/j.gloenvcha.2009.05.002

Braun, V., and V. Clarke. 2006. Using thematic analysis in psychology. Qualitative Research in Psychology 3(2):77-101. https://doi.org/10.1191/1478088706qp063oa

Brunner, R. D., and A. H. Lynch. 2010. Adaptive governance and climate change. American Meteorological Society, Boston, Massachusetts, USA. http://dx.doi.org/10.1007/978-1-935704-01-0

Calkin, D. E., M. P. Thompson, and M. A. Finney. 2015. Negative consequences of positive feedbacks in U.S. wildfire management. Forest Ecosystems 2(9). https://doi.org/10.1186/s40663-015-0033-8

Cary, G. J., I. D. Davies, R. A. Bradstock, R. E. Keane, and M. D. Flannigan. 2017. Importance of fuel treatment for limiting moderate-to-high intensity fire: findings from comparative fire modelling. Landscape Ecology 32(7):1473-1483. https://doi. org/10.1007/s10980-016-0420-8

Cash, D. W., and S. C. Moser. 2000. Linking global and local scales: designing dynamic assessment and management processes. Global Environmental Change 10(2):109-120. https://doi. org/10.1016/S0959-3780(00)00017-0

Chaffin, B. A, H. Gosnell, and B. A. Cosens. 2014. A decade of adaptive governance scholarship: synthesis and future directions. Ecology and Society 19(3):56. https://doi.org/10.5751/ES-06824-190356

Chaffin, B. C., and L. H. Gunderson. 2016. Emergence, institutionalization and renewal: rhythms of adaptive governance in complex social-ecological systems. Journal of Environmental Management 165:81-87. http://dx.doi.org/10.1016/j.jenvman.2015.09.003

Chapin, F. S., S. F. Trainor, P. Cochran, H. Huntington, C. Markon, M. McCammon, A. D. McGuire, and M. Serreze. 2014. Alaska. Pages 514-536 in J. M. Melillo, T. C. Richmond, and G. W. Yohe, editors. Climate change impacts in the United States: the third national climate assessment. U.S. Global Change Research Program, Washington, D.C., USA. https://doi.org/10.7930/ $\underline{\mathrm{J} 00 \mathrm{Z} 7150}$

Chapin, F. S., S. F. Trainor, O. Huntington, A. L. Lovecraft, E. Zavaleta, D. C. Natcher, A. D. McGuire, J. L. Nelson, L. Ray, M. Calef, N. Fresco, H. Huntington, T. S. Rupp, L. DeWilde, and R. L. Naylor. 2008. Increasing wildfire in Alaska's boreal forest: pathways to potential solutions of a wicked problem. BioScience 58(6):531-540. https://doi.org/10.1641/b580609
Cosens, B. A., R. K. Craig, S. Hirsch, C. A. (T.) Arnold, M. H. Benson, D. A. DeCaro, A. S. Garmestani, H. Gosnell, J. Ruhl, and E. Schlager. 2017. The role of law in adaptive governance. Ecology and Society 22(1):30. https://doi.org/10.5751/ES-08731-220130

Cosens, B., L. Gunderson, C. Allen, and M. H. Benson. 2014. Identifying legal, ecological and governance obstacles, and opportunities for adapting to climate change. Sustainability 6 (4):2338-2356. https://doi.org/10.3390/su6042338

Cosens, B. A., L. Gunderson, and B. C. Chaffin. 2018. Introduction to the Special Feature Practicing Panarchy: Assessing legal flexibility, ecological resilience, and adaptive governance in regional water systems experiencing rapid environmental change. Ecology and Society 23(1):4. https://doi. org/10.5751/ES-09524-230104

Craig, R. K., A. S. Garmestani, C. R. Allen, C. A. Arnold, H. Birge, D. A. DeCaro, A. K. Fremier, H. Gosnell, and E. Schlager. 2017. Balancing stability and flexibility in adaptive governance: an analysis of tools available in U.S. environmental law. Ecology and Society 22(2):3. https://doi.org/10.5751/ES-08983-220203

Crona, B. I., and J. N. Parker. 2012. Learning in support of governance: theories, methods, and a framework to assess how bridging organizations contribute to adaptive resource governance. Ecology and Society 17(1):32. https://doi. org/10.5751/ES-04534-170132

DeCaro, D., B. C. Chaffin, E. Schlager, A. S. Garmestani, and J. B. Ruhl. 2017. Legal and institutional foundations of adaptive environmental governance. Ecology and Society 22(1):32. https:// doi.org/10.5751/ES-09036-220132

Dietz, T., E. Ostrom, and P. C. Stern. 2003. The struggle to govern the commons. Science 302(5652):1907-1912. https://doi. org/10.1126/science.1091015

Djalante, R., C. Holley, and F. Thomalla. 2011. Adaptive governance and managing resilience to natural hazards. International Journal of Disaster Risk Science 2(4):1-14. https:// doi.org/10.1007/s13753-011-0015-6

Duffy, P. A., J. E. Walsh, J. M. Graham, D. H. Mann, and T. S. Rupp. 2005. Impacts of large-scale atmospheric-ocean variability on Alaskan fire season severity. Ecological Applications 15 (4):1317-1330. https://doi.org/10.1890/04-0739

Flannigan, M. D., B. M. Wotton, G. A. Marshall, W. J. de Groot, J. Johnston, N. Jurko, and A. S. Cantin. 2016. Fuel moisture sensitivity to temperature and precipitation: climate change implications. Climatic Change 134(1-2):59-71. https://doi. org/10.1007/s10584-015-1521-0

Folke, C., T. Hahn, P. Olsson, and J. Norberg. 2005. Adaptive governance of social-ecological systems. Annual Review of Environment and Resources 30:441-473. https://doi.org/10.1146/ annurev.energy.30.050504.144511

Folke, C., L. Pritchard, F. Berkes, J. Colding, and U. Svedin. 2007. The problem of fit between ecosystems and institutions: ten years later. Ecology and Society 12(1):30. https://doi.org/10.5751/ ES-02064-120130

Huitema, D., E. Mostert, W. Egas, S. Moellenkamp, C. PahlWostl, and R. Yalcin. 2009. Adaptive water governance: assessing 
the institutional prescriptions of adaptive (co-)management from a governance perspective and defining a research agenda. Ecology and Society 14(1):26. https://doi.org/10.5751/ES-02827-140126

Hull, T., and L. Leask. 2000. Dividing Alaska, 1867-2000: changing land ownership and management. Alaska Review of Social and Economic Conditions 32(1). [online] URL: http://www. iser.uaa.alaska.edu/Publications/Landswebfiles/lands.pdf

Jandt, R., K. Joly, C. R. Meyers, and C. Racine. 2008. Slow recovery of lichen on burned caribou winter range in Alaska tundra: potential influences of climate warming and other disturbance factors. Arctic, Antarctic, and Alpine Research 40 (1):89-95.

Johnstone, J. F., F. S. Chapin III, T. N. Hollingsworth, M. C. Mack, V. Romanovsky, and M. Turetsky. 2010. Fire, climate change, and forest resilience in interior Alaska. Canadian Journal of Forest Research 40(7):1302-1312. https://doi.org/10.1139/ $\underline{\mathrm{X} 10-061}$

Joly, K., P. A. Duffy, and T. S. Rupp. 2012. Simulating the effects of climate change on fire regimes in Arctic biomes: implications for caribou and moose habitat. Ecosphere 3(5):1-18. https://doi. org/10.1890/ES12-00012.1

Jones, B. M., G. Grosse, C. D. Arp, E. Miller, L. Liu, D. J. Hayes, and C. F. Larsen. 2015. Recent Arctic tundra fire initiates widespread thermokarst development. Scientific Reports 5:15865. https://doi.org/10.1038/srep15865

Kasischke, E. S., and M. R. Turetsky. 2006. Recent changes in the fire regime across the North American boreal region-spatial and temporal patterns of burning across Canada and Alaska. Geophysical Research Letters 33(13):L13703. https://doi. org/10.1029/2006GL026946

Kasischke, E. S., D. L. Verbyla, T. S. Rupp, A. D. McGuire, K. A. Murphy, R. Jandt, J. L. Barnes, E. E. Hoy, P. A. Duffy, M. Calef, and M. R. Turetsky. 2010. Alaska's changing fire regimeimplications for the vulnerability of its boreal forests. Canadian Journal of Forest Research 40(7):1313-1324. https://doi. org/10.1139/X10-098

Kelly, R., M. L. Chipman, P. E. Higuera, I. Stefanova, L. B. Brubaker, and F. S. Hu. 2013. Recent burning of boreal forests exceeds fire regime limits of the past 10,000 years. Proceedings of the National Academy of Sciences of the United States of America 110(32):13055-13060. https://doi.org/10.1073/pnas. 1305069110

Kettl, D. F. 2000. The transformation of governance: globalization, devolution, and the role of government. Public Administration Review 60(6):488-497. https://doi.

org/10.1111/0033-3352.00112

Kleindl, W. J., P. C. Stoy, M. W. Binford, A. R. Desai, M. C. Dietze, C. A. Schultz, G. Starr, C. L. Staudhammer, and D. J. A. Wood. 2018. Toward a social-ecological theory of forest macrosystems for improved ecosystem management. Forests 9(4):200. https:// doi.org/10.3390/f9040200

Knapp, C. N., and S. F. Trainor. 2015. Alaskan stakeholderdefined research needs in the context of climate change. Polar Geography 38(1):42-69. https://doi.org/10.1080/1088937X.2014.999844

Koontz, T. M., D. Gupta, P. Mudliar, and P. Ranjan. 2015. Adaptive institutions in social-ecological systems governance: a synthesis framework. Environmental Science \& Policy 53:139-151. https://doi.org/10.1016/j.envsci.2015.01.003

Mack, M. C., M. S. Bret-Harte, T. N. Hollingsworth, R. R. Jandt, E. A. G. Schuur, G. R. Shaver, and D. L. Verbyla. 2011. Carbon loss from an unprecedented Arctic tundra wildfire. Nature 475:489-492. https://doi.org/10.1038/nature10283

Mann, D. H., T. S. Rupp, M. A. Olson, and P. A. Duffy. 2012. Is Alaska's boreal forest now crossing a major ecological threshold? Arctic, Antarctic, and Alpine Research 44(3):319-331. http://doi. org/10.1657/1938-4246-44.3.319

Melvin A. M., G. Celis, J. F. Johnstone, A. D. McGuire, H. Genet, E. A. G. Schuur, T. S. Rupp, and M. C. Mack. 2018. Fuelreduction management alters plant composition, carbon and nitrogen pools, and soil thaw in Alaskan boreal forest. Ecological Applications 28(1):149-161. https://doi.org/10.1002/eap.1636

Melvin, A. M., J. Murray, B. Boehlert, J. A. Martinich, L. Rennels, and T. S. Rupp. 2017. Estimating wildfire response costs in Alaska's changing climate. Climatic Change 141(4):783-795. https://doi.org/10.1007/s10584-017-1923-2

Moritz, M. A., M.-A. Parisien, E. Batllori, M. A. Krawchuk, J. Van Dorn, D. J. Ganz, and K. Hayhoe. 2012. Climate change and disruptions to global fire activity. Ecosphere 3(6):1-22. https://doi. org/10.1890/ES11-00345.1

Morrison, T. H., W. N. Adger, K. Brown, M. C. Lemos, D. Huitema, and T. P. Hughes. 2017. Mitigation and adaptation in polycentric systems: sources of power in the pursuit of collective goals. Wiley Interdisciplinary Reviews-Climate Change 8(5):e479. https://doi.org/10.1002/wcc.479

Moseley, C., and S. Charnley. 2014. Understanding microprocesses of institutionalization: stewardship contracting and national forest management. Policy Sciences 47(1):69-98. https:// doi.org/10.1007/s11077-013-9190-1

North, M., B. M. Collins, and S. Stephens. 2012. Using fire to increase the scale, benefits, and future maintenance of fuels treatments. Journal of Forestry 110(7):392-401. https://doi. org/10.5849/jof.12-021

Olsson, P., C. Folke, and F. Berkes. 2004. Adaptive comanagement for building resilience in social-ecological systems. Environmental Management 34(1):75-90. https://doi.org/10.1007/s00267-003-0101-7

Olsson, P., C. Folke, and T. P. Hughes. 2008. Navigating the transition to ecosystem-based management of the Great Barrier Reef, Australia. Proceedings of the National Academy of Sciences of the United States of America 105(28):9489-9494. https://doi. org/10.1073/pnas.0706905105

O'Reilly, M., and N. Parker. 2013. 'Unsatisfactory saturation': a critical exploration of the notion of saturated sample sizes in qualitative research. Qualitative Research 13(2):190-197. http:// dx.doi.org/10.1177/1468794112446106

Pastick, N. J., P. Duffy, H. Genet, T. S. Rupp, B. K. Wylie, K. D. Johnson, M. T. Jorgenson, N. Bliss, A. D. McGuire, E. E. Jafarov, and J. F. Knight. 2017. Historical and projected trends in landscape drivers affecting carbon dynamics in Alaska. Ecological Applications 27(5):1383-1402. https://doi.org/10.1002/eap.1538 
Patton, M. Q. 2015. Qualitative research \& evaluation methods: integrating theory and practice. Fourth edition. SAGE, Thousand Oaks, California, USA.

Rijke, J., R. Brown, C. Zevenbergen, R. Ashley, M. Farrelly, P. Morison, and S. van Herk. 2012. Fit-for-purpose governance: a framework to make adaptive governance operational. Environmental Science and Policy 22:73-84. http://dx.doi. org/10.1016/j.envsci.2012.06.010

Rupp, T. S., P. Duffy, M. Leonawicz, M. Lindgren, A. Breen, T. Kurkowski, A. Floyd, A. Bennett, and L. Krutikov. 2016. Climate simulations, land cover, and wildfire in Alaska. Pages 17-52 in Z. Zhu and A. D. McGuire, editors. Baseline and projected future carbon storage and greenhouse-gas fluxes in ecosystems of Alaska. Professional Paper 1826. U.S. Geological Survey, Reston, Virginia, USA.

Scheffer, M., M. Hirota, M. Holmgren, E. H. Van Nes, and F. S. Chapin III. 2012. Thresholds for boreal biome transitions. Proceedings of the National Academy of Sciences of the United States of America 109(52):21384-21389. https://doi.org/10.1073/ pnas. 1219844110

Schoennagel, T., J. K. Balch, H. Brenkert-Smith, P. E. Dennison, B. J. Harvey, M. A. Krawchuk, N. Mietkiewicz, P. Morgan, M. A. Moritz, R. Rasker, M. G. Turner, and C. Whitlock. 2017. Adapt to more wildfire in western North American forests as climate changes. Proceedings of the National Academy of Sciences of the United States of America 114(18):4582-4590. https://doi. org/10.1073/pnas.1617464114

Schultz, C. A., M. P. Thompson, and S. McCaffrey. 2019. Forest Service fire management and the elusiveness of change. Fire Ecology, in press.

Schuur, E. A. G., J. Bockheim, J. G. Canadell, E. Euskirchen, C. B. Field, S. V. Goryachkin, S. Hagemann, P. Kuhry, P. M. Lafleur, H. Lee, G. Mazhitova, F. E. Nelson, A. Rinke, V. E. Romanovsky, N. Shiklomanov, C. Tarnocai, S. Venevsky, J. G. Vogel, and S. A. Zimov. 2008. Vulnerability of permafrost carbon to climate change: implications for the global carbon cycle. BioScience 58 (8):701-714. https://doi.org/10.1641/B580807

Stephens, S. L., J. K. Agee, P. Z. Fulé, M. P. North, W. H. Romme, T. W. Swetnam, and M. G. Turner. 2013. Managing forests and fire in changing climates. Science 342(6154):41-42. https://doi. org/10.1126/science.1240294

Todd, S. K., and H. A. Jewkes. 2006. Wildland fire in Alaska: a history of organized fire suppression and management in the Last Frontier. Bulletin Number 114. University of Alaska Fairbanks, USA. [online] URL: https://www.uaf.edu/files/snre/B114.pdf

Trainor, S. F., M. Calef, D. Natcher, F. S. Chapin III, A. D. McGuire, O. Huntington, P. Duffy, T. S. Rupp, L. DeWilde, M. Kwart, N. Fresco, and A. L. Lovecraft. 2009. Vulnerability and adaptation to climate-related fire impacts in rural and urban interior Alaska. Polar Research 28(1):100-118. https://doi. org/10.1111/j.1751-8369.2009.00101.X

U.S. Department of the Interior, Bureau of Indian Affairs, Bureau of Land Management, Fish and Wildlife Service, National Park Service, U.S. Department of Agriculture, Forest Service, and State of Alaska, Department of Natural Resources (USDOI BIA et al.). 2016. Alaska master cooperative wildland fire management and Stafford Act response agreement. Washington, D.C., USA. [online] URL: https://fire.ak.blm.gov/administration/asma.php

Wotton, B. M., M. D. Flannigan, and G. A. Marshall. 2017. Potential climate change impacts on fire intensity and key wildfire suppression thresholds in Canada. Environmental Research Letters 12(9):095003. https://doi.org/10.1088/1748-9326/aa7e6e

Wyborn, C., and R. P. Bixler. 2013. Collaboration and nested environmental governance: scale dependency, scale framing, and cross-scale interactions in collaborative conservation. Journal of Environmental Management 123:58-67. https://doi.org/10.1016/j. jenvman.2013.03.014

Yin, R. K. 2016. Qualitative research from start to finish. Second edition. Guilford, New York, New York, USA.

Young, A. M., P. E. Higuera, P. A. Duffy, and F. S. Hu. 2017. Climatic thresholds shape northern high-latitude fire regimes and imply vulnerability to future climate change. Ecography 40 (5):606-617. https://doi.org/10.1111/ecog.02205 
Appendix 1: Selected interview excerpts. Excerpts appear in order of reference in the main text. Headings match those found in the section entitled Results and Discussion. Any edits to an interviewee's original wording have been made for clarity or to maintain the interviewee's confidentiality.

\section{Management challenges and needed responses}

1. What you ultimately have to do is prioritize the resources that you have and try to direct them towards the most important incidents or issues first. That's something you see in larger fire seasons up here, is that resources become thin and incidents are prioritized so you can figure out where to allocate limited resources, because it's not possible to give every incident what it may need or what it may want. - Jurisdictional agency interviewee

2. There's a sense of nervousness as far as not being able to handle this new fire load that we all understand is coming. - Jurisdictional agency interviewee

3. [T]hese natural fires are growing, so ... we'll probably at some point in time have to consider what we're going to do around these "critical" and "full" areas that are protecting communities, whether we have the financial means and the public support to do prescribed fire or mechanical, or are we going to have to fall back and start ... increasing the size of these "criticals" and "fulls," just to accommodate the additional frequency and the potential size and scope of those fires. So that's one of the things I'm toying with, but that comes at a cost, and you start increasing the "fulls" and "criticals," and then that will draw resources that may be utilized elsewhere. - Jurisdictional agency interviewee

4. [T] he thing that's been hit the hardest, really, ... by far is in the Department of the Interior's fuels budget. ... We never really had a large fuels program here in Alaska and the acres of fuel treatments that we've been able to produce ... There are just some major budgetary limitations in terms of what's possible or what's conceivable for fuels treatments at this point, I think within really any agency. - Jurisdictional agency interviewee

5. [T]he State of Alaska has never invested any general fund money in fuel mitigation work. All the fuel mitigation that's been done in Alaska has been federally funded in one way or another, either through [the U.S. Department of the Interior] or the U.S. Forest Service, and competitive projects that the State secures through various federal sources. That ... has been a real frustration, because the State could save themselves a lot of money, and the Funny River Fire and the fuel break down there definitely demonstrated that. - Protection agency interviewee

6. [Fuel management is] something that I would like to do more of, but really, funding has just been leaner and leaner to get that. We rely almost solely on WUI [wildland-urban interface] grants to do that. And they're just more competitive, [with] less funding and more people probably applying. - Protection agency interviewee 
7. The problem is that Alaskans are very independent, for the most part. And a lot of people up here just want to be left alone. So, that's why they're here. And so, also communicating with [people] off the road system is very difficult logistically ... getting the word out and educating everybody. So, that is another challenge, but we are really looking at this as a training opportunity to educate the public on their responsibility, and not ours. Basically, saying we may not be there for you, so it's up to you to be prepared. So, if a fire does happen, if we're not there, your house still will be safe, because of the Firewise techniques that we've educated them on. - Protection agency interviewee

8. The message we're trying to send is we're doing some strategic fuel break mitigation work, mostly on public lands, but there's some on private lands. But we'd ask the people that live there to do work on their own land, and it just strengthens the integrity of the community from a fire resilience standpoint. When we get people that are within the community that take action on their own property, it makes that whole community more defensible and more resilient. - Jurisdictional agency interviewee

9. All Lands/All Hands_-it's legacy. I mean, folks have been coming together for spruce bark beetles and now we meet twice a year. We share project information. It has provided avenues for working with different ... types of funding. ... We get together, and we prioritize treatments, and we utilize those that have the skillset within that group [to] do modeling, you know, IFTDSS [Interagency Fuel Treatment Decision Support System] modeling. So, we take the various skillsets, and various landowners, and various things that everyone brings to the table, and I think we're just capitalizing on bringing those various skills together. ... Whoever has the proper tool can offer that as a cooperative instead of everybody trying to do separate things. So that builds strength in that group in being able to accomplish some pretty broad-scale projects. ... When [non-local fire crews] see All Lands/All Hands, they go, "Wow, what a cool model." So, kind of some groundbreaking stuff here that's been going on for quite a while. - Jurisdictional agency interviewee

10. There was a relatively significant spruce bark beetle outbreak in the late ' 90 's that made the cause for action amongst land management agencies to deal with it somehow. They formed this All Lands/All hands group, and that was the original intent behind it. Since that time, ... the All Lands/All Hands has continued, and it has changed over time a little bit. Now we're talking about strategic fuel breaks, as opposed to dealing with bark beetles. But it's not just about fire. I mean there's all sorts of other stuff going on, because it truly is all hands, and it is all lands, and there are representatives from each agency in multiple disciplines talking about collaborative projects that are ongoing. We meet, at a minimum, twice per year. And it's just a way to put everybody up from the Kenai Peninsula in the same room, at the same time and place, to talk about how we can help each other achieve ultimately very similar objectives. Each agency has their own unique niche. The Refuge is here for the wildlife, and the Forest Service is multiple use. But all in all, we're all here for the same thing. Jurisdictional agency interviewee 
11. [T] hey're coming together and they're sending a consistent message as this cooperative, as opposed to each agency sending their own message. The reason that's important is that there's so many players at stake here on the Kenai Peninsula, that we wanted to simplify and send a consistent message amongst all the agencies. That's what we're working on. - Jurisdictional agency interviewee

12. I think a lot [of the success of the Kenai Peninsula All Lands/All Hands group] has to do with the makeup of ... the Peninsula [as] a peninsula. It's got a higher population, bigger road network, organized governments, a lot of federal agencies. They made it work. I think initially the support of the [Kenai Peninsula] Borough was significant and [made it] easy for the federal agencies to jump on board, [as well as] state and other agencies. If you look at the rest of the state of Alaska, the Anchorage-[Matanuska-Susitna] area probably follows right behind Kenai with regard to collaboration and projects. Funding was received to mitigate the spruce beetle in Anchorage and Greater Palmer area. There's not an All Hands/All Lands group, but there certainly [has] been collaboration between state, and federal, and municipal entities. Outside of that, probably the Golden Heart City up there. Then it's just a matter of people and values, from my perspective. - Protection agency interviewee

13. There's cultural challenges because people haven't been doing [prescribed burning] regularly at the scale and intentions that we are seeking. We're kind of coming in with: they've done it in the past, and they do prescribed fire now within specific scopes, but we're saying, "Hey, let's burn 1000 acres a year on the Kenai Peninsula, or 3000 acres a year." ... These are different; this is not what we're used to here. We have a ways to go to with this program. We're just barely starting, but I see potential, because habitat enhancement, prescribed fires, these two things can be paired with wildland fire mitigation for communities, and we've got a lot of tiny communities or little groups of parcels that have structures on them that would otherwise have to be protected, so if we work with those allotments or other private land owners to protect them, and then use prescribed fire near them, then prescribed fires will eventually add that fire protection on a larger scale. I think there is great potential to expand the use of fire. - State agency interviewee

14. I mean that is the premise, is that strategic fuel breaks are allowing the decision makers the ability to manage a fire for multiple objectives, rather than we got to put this fire out because it's close to town. ... One of those objectives being allowing fire to burn in its natural state, as long as it does it in a way that is away from town and minimizes impacts to the community. - Jurisdictional agency interviewee

15. When the fires happen in some of the northern latitudes, where you don't have them very often, and it burns off the lichen, that takes a long time to recover, like maybe up to 50 years. And so then, the caribou migratory patterns are shifted, and just their forage availability is changed. That could have an impact on their abundance, on their movement patterns, and then that influences how people hunt them, whether it's you and I going out for a caribou or whether it's a community [that] needs caribou for their subsistence requirements because they 
don't have other resources out there. Yeah, that could have really big impacts on the livelihoods of a lot of people, for sure, as well as the animals. - State agency interviewee

16. [The management unit] decided to actually suppress ... inside long-term [old-growth black spruce management areas]. ... We don't want [all of the old-growth black spruce] to go up in one fire. ... That decision was made for two reasons: the sense of well-being that Native subsistence hunters have when they're out on the landscape in the wintertime with snowmobiles. If they're out in the middle of a two-year-old burn, their sense of well-being is not good compared to if they're in a forest. So, [the management unit responds] to human concerns and [does] that suppression. It was fairly controversial. A lot of pressure ... to just allow natural fire everywhere. - Jurisdictional agency interviewee

17. [E]ven though their chunk of lichen is relatively small, [the management unit] justified that management option change because they felt like having that opportunity there would potentially move caribou down past a couple of villages ... [providing] these subsistence opportunities for them. - Protection agency interviewee

18. [T] he issue with cabins, and it's constantly an issue up here, is whether or not a cabin is going to receive protection or not. Traditionally, and over the years, we've cataloged all of the cabins, and we call it Known Sites. ... [W] have a Known Sites Database that includes the cabins that are scattered all across Alaska. They could be on Fish and Wildlife Service Land, [Bureau of Land Management], [National] Park Service, private, [Bureau of Indian Affairs], State, [U.S.] Forest Service, I mean, it doesn't matter. If it's out there, we try to know about it. Having said that, there's probably hundreds, if not thousands we don't know about, and we're constantly updating and adding to the Known Sites Database. ... Each agency has a cabin protection policy, and not all the agencies are aligned with their cabin protection policies. Each agency is a little bit different. ... It's not really a challenge necessarily, so much as we just have to be constantly checking with the jurisdictional agency ... about their position on whether they want that cabin protected or not, because their policies change over time, as well. - Protection agency interviewee

19. We're talking more about [accepting] risk in the kinds of things that you have available and are paying for, for a given danger level. If you're at a moderate ... danger level, some of our stations will staff much differently than another station that's at the same danger level. That's usually based on personal experience in the managers on the station; that gets down to personalities, and those are the things that are hard to manage. It's not cut and dry, you do this, or you do that. That's the level of risk I'm trying to quantify. ... [Many managers] would argue [that] if we have an air tanker or a load of jumpers, an agency crew, and extra [Emergency Firefighters] in our back pocket, we'll be more successful in our initial attack. That's where that experience piece comes in. Maybe it will, maybe it won't. - Protection agency interviewee 
20. You're doing point protection on a large fire, and you go out there and you got a plan; maybe it's ... to contain it at a river or something, a natural barrier, but then you get a little bit of [precipitation], but not enough to do too much damage to the fire, but it stops you from performing your operation. And so, what we'll do sometimes is we'll end up with these Type III fires that last all summer long. They just nickel and dime you to death, and all of a sudden, you've spent $\$ 10$ million to protect something that's not that valuable. - Protection agency interviewee

21. There's been a lot of talk-like way background talk, not official talk-about carbon sequestration, and [whether] we need to be looking at certain times of the year, or certain conditions, like when it's really dry and things are going to burn really deep, [to suppress] fires in certain areas. But I haven't seen any action taken on it. - Protection agency interviewee

22. [T]wo [Native] Corporations ... are in the process of selling carbon credits for forest lands, [meaning] for the above-ground biomass. [One of those Corporations] has started the process to request changes in the initial response [option] from "limited" to "full." - Protection agency interviewee

23. If we decided carbon sequestration was really important [and] we just needed to not let any fires burn up here, we could put the whole state into "full" protection. And, what would that change about how we manage fire up here? I'm guessing it wouldn't change as much as you would expect, because it's not likely we're going to get a ton more resources or money to put all those fires out. So, we're still going to have to prioritize ... and we're still going prioritize stuff that's threatening life, and communities, and property, and that type of stuff. Protection agency interviewee

\section{Adaptive structures and processes}

24. Having that need for communication between the jurisdictional and the protection agencies, we have a pretty good working relationship with all the other agencies. ... It's not one of those, "I haven't talked to that individual in a couple of months;" it's, "I haven't talked to that individual in a couple hours" about something. - Protection agency interviewee

25. Yeah, I think we have to keep working on [reconciling fire management policy among agencies], and that's why this [Alaska] Interagency [Wildland] Fire Management Plan and this [Alaska Statewide] Annual Operating Plan are really important documents. That's why it's important for us to have our spring interagency meetings and our fall interagency meetings, so that people can have a little time to talk when things aren't on fire. You know, a little bit in the springtime you're thinking about what's coming up ahead of you, and in the fall, you're doing a little review of what happened during the season, and what issues were there, [and whether we can] resolve them. Usually, they get assigned out for people to think 
about and try to address in the wintertime before next fire season. Whatever issues we come up with. - Jurisdictional agency interviewee

26. [The Alaska Fire Service] maintains a really good working relationship with all of the entities and [keeps track of] what their goals and objectives are. We do have pre-fire [season] meetings, and post-fire [season] meetings, and coordination with the agencies themselves, where they come in and sit down to work with us. - Jurisdictional agency interviewee

27. Another [channel of communication] is through the Alaska Interagency [Wildland Fire] Management Plan, where we have identified fire management options for ... initial response. ... Everybody should be in agreement on that. They're not always correct because it's a big state, and [the agencies] have been handling those updates made to that management option layer to get it to be more reflective of what the [initial response] needs are. - Protection agency interviewee

28. [E]very time we do find [new valued points], either it's on a flight, [a] detection flight, or some [smoke]jumpers landed [on] a fire, and it's on a cabin that was not [in] our Known Sites [Database]. Then we enter it that into that [database]. We have our means of collecting data remotely, either on a remote device, [which,] when you get back into civilization, ... populates into that database, or we could fill it out by hand, and then [wait until we] get back [for] everything [to get] populated into there. We're very diligent on getting that updated as much as possible. It's pretty thought-out. There's a lot of information. If you look at just the amount of land mass that Alaska has, it's hard to capture everything out there, but it captures ... a pretty high percentage of it. - Protection agency interviewee

29. [The Kenai All Lands/All Lands group] cooperators have formed another group called the Kenai Peninsula Fuel Break Working Group, and that is a six-party working group that includes Alaska Department of Fish and Game, the Kenai Peninsula Borough, State [Division of] Forestry, the [U.S.] Fish and Wildlife Service, Cook Inlet Region, Inc., and Chugachmiut, which is a nonprofit native corporation. Those six parties have come together and formed this fuel break working group, and their task is to identify areas and prioritize areas ... for strategic fuel breaks. ... [W]e had all these public land management entities, and we wanted to come together, and prioritize, and get everybody's objectives on the same page. ... [W]e're moving forward under this interagency approach here on the Kenai because it's more effective to work as a group as opposed to each agency individually working. Jurisdictional agency interviewee

30. [W] take part [in the Alaska Wildland Fire Coordinating Group] ... fire research needs list every year, which [the Alaska Wildland Fire Coordinating Group turns] over to the [Alaska Fire Science] Consortium, which ... uses that to help evaluate ... what types of proposals to fund for fire research in Alaska. - Alaska Native organization interviewee

31. The [Alaska Fire Science] Consortium brings federal land managers together with scientists to sort of bridge that gap. - Protection agency interviewee 
32. I try to participate in as many webinars and conferences as I can. I know there's a big emphasis on climate change and how we can expect fire regimes to change, especially with changes in successional responses to fire on the landscape. I would definitely support a continuation of that and looking toward that scientific knowledge to help look at what that potential is for the future. That's going to help drive how we have to respond as an agency to be prepared; so, being tied in with that research environment is key for fire managers. I think the Joint Fire Science [Program] folks do a very good job of querying the fire managers and asking, "What information do you want to learn about? Where do you want us to emphasize research? We can go find research that's taking place." I think there's a great relationship right now [between] the fire managers and the [Joint Fire Science Program]. - Protection agency interviewee

33. And I think as fire regimes are changing ... the resources side [is having] to sit down and have more conversations with the fire side and [look] at fire science. The one thing that we do take advantage of is, because of [the Alaska Fire Service's] increased size and capacity, ... having a robust fire science side of our program integrated into the fire [management side of our] program. ... But it's just a conscious decision on our part to [have] those ... come together and have that dialogue and discussion. - Jurisdictional agency interviewee

34. [P] robably after 2004, 2005, we burned up a bunch of [the] Porcupine caribou [herd's range]. And then, people started worrying that we were burning up all this [caribou forage] lichen and we were going to be negatively impacting [caribou]; even though moose respond well, we were negatively impacting caribou. ... There was some research done and there [were] some management option changes made to kind of limit the amount of old-growth lichen habitat that would burn. - Protection agency interviewee

35. [C]apturing all the fuels treatments that we've got in place right now would be hugely helpful. That's actually something that we were going to try and work on this spring. Protection agency interviewee

36. [T] he effects of climate change are generally widely accepted [in Alaska], and much more broadly acknowledged than in some of the states where I've worked. I think it's definitely something that's taken very seriously here. We understand that our fire season is increasing. ... If you look over the course of a number of years, the fire season is [starting] earlier, going later. We're getting bigger and very intense fires, so there's a lot of concern there. - State agency interviewee

37. [The state legislature needs] to understand what [the fire management agencies] do, how [they] do it. ... [The State has] been very supportive of the fire program, at least during the season, when we actually have fire, and even during the non-fire part of the year, but not to the point that it's been a priority for them, legislatively, or budgetarily [ sic $]$... [O]nce they understand the story, there's a better chance that will resonate in a way that will help with a policy change, or financial assistance. - Protection agency interviewee 
38. The [U.S.] Department of the Interior ... has developed models to help try and guide how the budget should be distributed amongst the different Department of the Interior agencies. Again, that's not just looking at Alaska; that's looking at the entire country. Those efforts are always very challenging because they're trying to come up with some way to model something across the entire country, where you've got a whole different range of what's important versus what's not important. Most recently there was the [Department of the Interior] risk-based model, I think is what it was called. There was one input in it valued sage-grouse habitat and that was a priority of the administration at that time. There [were] a number of initiatives regarding sagebrush habitat. That was a plus if an area had lots of habitat for that particular species. We don't have any of that in Alaska. That was sort of seen as something that didn't really favor Alaska regardless of which agency you're talking about. ... The State of Alaska is really the only entity that when they're trying to defend a budget they're speaking to an Alaska-only audience. We in [our agency] are obviously dealing with [the entire, nationwide agency] across all the regions, and when you bring it up to the Department of the Interior level, they're looking at an even bigger thing where they're trying to determine what the balance should be, not only across the geographic extent of the country but between the different agencies of the Department of the Interior. - Jurisdictional agency interviewee

39. [The U.S. Department of the Interior] can model initial response success rate, minimizing acres burned. A lot of the [Bureau of Land Management] in the Lower 48, they are minimizing acres burned of sage-grouse habitat. You can model that pretty successfully. You can plan for that and you can staff for that. Here [in Alaska], where we're in a lot of cases not trying to minimize acreage burned, but minimize impact to a specific location, we've found it's extremely difficult to model, if not impossible, and extremely expensive to do. Protection agency interviewee

40. All allotments are in full protection. That's kind of the default up here. We're supposed to protect them. Like I said before, that's a huge resource commitment to do so. We're more than happy to do so, but sometimes it comes at the expense of protecting other things. We're always talking with the [U.S. Department of the Interior Bureau of Indian Affairs], especially once the fire season starts ramping up and we see we're getting short on resources, saying, "Hey, can we take these on a case by case basis? Or can we just protect the structures on the allotment and not worry about the whole 160 acres?" We always have that conversation with them to try to resolve some of the resource allocation prioritization issues that we experience. - Protection agency interviewee

41. [T] he Native allotments ... are all "full" suppression. And it's because of a ... policy, and [the agencies] don't want to deviate from that at all. ... [A] good portion of the resources go to trying to suppress fire on allotments or keep it away from allotments. Now, there [are] a lot of them that are located on rivers and stuff. That's where the vast majority of them are, and the ones that have structures usually get a little bit higher priority even than the other 
allotments. Some of them are located in areas where it is reasonable to protect them, but yeah, there's some [that are] kind of in the middle of nowhere, and there can be a lot of time and effort spent trying to keep fire off ... a chunk of black spruce or even a chunk of tundra that's in the middle of a bunch of other tundra that looks the same, and the surrounding [jurisdictional] agency just would prefer [that] fire play its natural role. - Protection agency interviewee

42. Sometimes [fire management personnel] don't want to accept [the allotment protection mandate], but they have to. - Alaska Native organization interviewee

43. We don't make judgment about [suppressing fire on or near allotments], but [it] is a resource heavy commitment [to do] so. You're usually cutting a big box around 160 acres of forested Alaska ecosystem, and that's no small task. I mean, it's doable, but it takes up a lot of resources to do that. We have to balance the need and availability of resources to do that versus the protection of these other things that are out there being threatened. Again, it's a roundtable discussion where we just kind of talk it out and cooperatively agree to a plan of action. - Protection agency interviewee

44. [The protection agency fire management officers], as that fire gets larger, [have] to make sure that they have continued to recognize that these additional jurisdictions have possible values that are threatened, and that can be difficult if you've got a lot of fire on the landscape, just keeping track of every one of them and making sure that all the jurisdictions are appropriately notified. - Protection agency interviewee

45. And so, a [protection agency fire management officer] ... that manages fire for multiple units ... should be familiar with all of those unit fire management plans that fall within [his or her] zone. And that can be difficult. These plans were historically paper documents, [approximately] 50- to 100-page documents with a bunch of appendices, [sitting] in a binder on the jurisdictional [agency fire management officer's] desk. And, because we have disconnected environments up here between the [protection] and the jurisdictional agencies, ... that plan is sitting, not necessarily ... helping [the protection agency fire management officer] out very much. So, really what we're trying to do now ... is to get that direction that's sitting in those binders in those jurisdictional offices ... out of there and available to the protecting [agency fire management officers] through the WFDSS [Wildland Fire Decision Support System], essentially. ... And that way, you don't have to have 20 binders on your desk and know which ones you need to dive into for an incident. That direction should pop up within the WFDSS system. - Protection agency interviewee

46. It's trust developed through relationships between the agencies, whether I'm working with a fire on [U.S. Department of the Interior National Park Service] lands that's threatening State lands, or working with Fairbanks Area Forestry, or working with Tanana [Fire Management] Zone for [fires] that are threatening [U.S. Department of the Interior Bureau of Land 
Management] lands. ... I think it's just about those relationships that makes it work. Jurisdictional agency interviewee

47. [I]t can be a bit of a challenge in regard to having staff available to support incident management teams. And then also in regard to having resource advisers ... out on the ground to help support our fire suppression and fire management decisions. I think that that's something that we struggle with a bit, and ... we need to be part of a more integrated team. Jurisdictional agency interviewee

48. [T] $]$ here's this whole fire world and some of the agency administrators or the line officers aren't necessarily sitting at the table to hear some of those discussions. And I think getting us to that point where [the agency administrators are] more a part of that thought process, and it's a normal thing that they actively participate in those [fire management meetings] to learn some of the challenges and incorporate that into some of their wildland fire decision making. - Jurisdictional agency interviewee

49. [I]n Alaska, because we've separated stuff out and the protecting agencies are disconnected from those units, ... they should be focusing on ... what that ... unit's specific values are, what their expectations are. ... [That is,] what they do want protected, ... [and] what is most important, and how much value is on it. - Protection agency interviewee

50. We recently had everything written up, had all the permits, had the burn plan written up [for], I think, a fairly small prescribed fire. ... [We] had everything ready, we were within the climatic conditions that had been specified as being appropriate, and when it came right down to it, State [Division of] Forestry, they just weren't comfortable. Even though everything was ready, conditions were perfect, or at least within the range of what was acceptable, they still were not willing to light that fire, just because, if something went wrong, it could have catastrophic effects. The other big issue is just convincing the [Division of] Forestry that this really is an important management option for us, and something that we should be doing. Then, obviously, we need to have the resources to be able to control the fire, should a big wind pick up and jump our fire line. There's just this general nervousness, and then, without having the financial resources at the moment to really cover our bases, we're really handcuffed at the moment. - State agency interviewee

51. The challenge is that ... because suppression has been such a dominating part of the fire program [in Alaska], it's difficult to get [to the] management side of it, which is growing. We really did not have that [in Alaska] historically, so there really wasn't that type of interaction in just adjusting culturally to bring that aspect of the fire program into the mainstream of resource management and make it more integrated and not segregated. ... And our challenge, and this is a management challenge, is to bring those more in tune together. In some [management areas] it's more successful than others. A lot of that is based on personalities, and perspectives, and culture. - Jurisdictional agency interviewee 
52. I think sometimes fuels management gets lumped into fire and it might be better funded by putting the fuels management program in with vegetation management, forestry, or one of the other programs that's already managing vegetation and let the fire folks work on the suppression side. - Jurisdictional agency interviewee

\section{Emergent practices and institutional change}

53. I think the fire management options, that whole predetermined initial response, is excellent. I would like to see that in the whole U.S. I just think it's the most amazing model. I applaud Alaska for pulling the entities together to agree on the Alaska Interagency Wildland Fire Management Plan that created this whole system. I also applaud our [Master] Agreement to realize efficiencies by not having everybody focused on hiring protection resources, ... [but rather focusing] efforts on the highest priority [land management] projects. - Jurisdictional agency interviewee

54. We're working together, and I think that's one of the most important parts. ... I mean, we have a real good model up here, the Alaska model, and it's pretty solid. - Jurisdictional agency interviewee

55. And that's the problem with our fire plan, is that it was a product of [the Alaska National Interest Lands Conservation Act], and that was the driving force in the funding to get these groups together to initiate the [Alaska Interagency Wildland Fire Management] Plan, or the plans that were then later consolidated into a single plan. But there really hasn't been a mechanism to bring that same group together, the current participants, and review the management options. ... They are supposed to be reviewed in the fall, because after the fire season, if you've done any non-standard responses, those individual responses are supposed to be reviewed between the protection agency and the jurisdictional [agency].... [Revision of the map] has been kind of piecemeal, and so it's just left up to the ambition of the individual land manager and [fire management officer]. It is not like an organized state-wide event. ... [The management options are] not applied evenly. - Protection agency interviewee

56. One thing that I say that the State has fallen down on, the Department of Natural Resources Division of Forestry, is involving [the] jurisdictional land people, the [Department of Natural Resources Division of] Mining, Land, and Water, [the Alaska Department of Health and Social Services Division of Behavioral] Health, [the] University [of Alaska]. At our spring meeting, the [federal jurisdictional agencies] were great. They brought in their district offices, their area offices, their jurisdictional [staff] involved in on fires, because those are the ones that do the land plans, but they [are] also involved in the fire side because sometimes [they] say, "This is what I want on my land," and it's up to coordinating it with the fire protection [agency] to say that this is going to happen. [Although the Alaska Division of Forestry protects] private, municipal, and state lands, ... other than giving permission to [use] heavy equipment, sometimes [the Division of Forestry doesn't] involve the head person for 
[the Division of Mining,] Land, [and Water]. They're the ones that are doing the land planning and so forth. ... The feds work as a joint effort. Their jurisdictional [fire management officer] and their fire protection [fire management officer] have to work together. ... [The Division of Forestry is] trying to do more of that. [It's] trying to say, "Hey the area that you think that you're going to put your remote subdivision is a fire trap. It's a very dangerous area." - Protection agency interviewee

57. One of the things that came out of [our fire and fuels review] was [the] agency administrators weren't actively going out on fires, they weren't actively participating in meetings, and so [that is now] part of the performance [review] for [the agency administrators], that they start attending these more. - Jurisdictional agency interviewee

58. [I]t could be a multi-agency group. That's their task, to re-look at the fire plan and protection level. ... They fully understand all the procedures they need to follow, ... and I think if you had a group that did that, it would get pretty good at going through that process. - Protection agency interviewee

59. [T] he [Kenai Peninsula] All Hands/All Lands group, ... that collaboration started when it was realized that a significant [spruce] bark beetle infestation had decimated just a tremendous amount of acreage down at Kenai. ... There was a lot of funding made available to the Kenai Peninsula Borough to deal with spruce bark beetle mortality on borough lands. Obviously, the federal agencies down there, [such as] the [U.S. Department of the Interior] Fish and Wildlife Service, had an opportunity to join in with the Borough and State to access the funding and to create projects. [The success of that initial collaboration] was a matter of values, people, numbers of people, and available funding to go forth. The group has continued to meet. The level of funding certainly has dropped off, but not entirely. They've continued to collaborate and serve a role there, a collaborative role to continue on. They've continued to conduct projects, [even though] the acreage impacted [by the spruce bark beetle outbreak] today is a lot less than what it was in 1990's and early 2000's. Probably another factor that influenced [the group's success] was the NPI [LLC], an organization that was manufacturing high end wood chips that were being exported to Asia, so [the All Lands/All Hands group] had an outlet for the material. Where we've had people and values and desire to collaborate and conduct mitigation projects, they occur, but like anything, you really need a community champion or champion organization, somebody to take the lead. The All Hands/All Lands group down there in Kenai has certainly served that [role]. [U.S. Department of Agriculture] Forest Service, [U.S.] Fish and Wildlife Service, State of Alaska, ANCSA [Native] Corporations, Kenai [Peninsula] Borough, [U.S. Department of the Interior Bureau of Land Management] - they've all been part of it. - Protection agency interviewee

60. This Sterling fuel break is probably the most recent example, where these guys [on the Kenai Peninsula All Lands/All Hands group] get together and say, "You know, we've got a real threat or issue to this community here, and if we put in a fuel break, it would buy us a lot of opportunity as far as effectively suppressing a fire and keeping it out of the community." 
From there, they ... start talking about how they can share resources, and how they can share funding, and how [they] can put this all together. ... That's how [the All Lands/All Hands] group has evolved there. - Borough agency interviewee

61. The beauty of these cooperatives and working groups is that funding typically gets leveraged in those scenarios, meaning, while the [U.S. Department of the Interior] Fish and Wildlife Service [can come] to the table with X amount of dollars, and [the Alaska Department of] Fish and Game can apply for grant funding, because [they're] in partnership together, [Fish and Game] can demonstrate through the grant application process that [their] partners came to the table with X number of dollars, and this is why Fish and Game is applying for funding. The intent is to leverage cooperative funds together to achieve a common goal. Everybody comes to the table with an attribute; some of it's money, some of it's a planning function, some of it's land ownership. And that's where [Cook Inlet Region, Inc.,] comes into play, is that they're the biggest private land owner on the Kenai Peninsula. And many of these fuel break locations are on or adjacent to [Cook Inlet Region, Inc.,] lands. ... One of the other attributes is the workforce. And that's where Chugachmiut comes into play, is that Chugachmiut is providing the lion's share of the work force, the people power. They have the Yukon Fire Crew that works for them through a grant. And so, they're able to actually implement the work. - Jurisdictional agency interviewee

62. I think the big one there is ... all agencies in Alaska look real hard at this whole allotment protection requirement. It's a federal requirement, but it's not achievable, really, and we need to look at doing something different with that. - Protection agency interviewee

63. [T] o be honest, ... we have this paper policy we're supposed to follow, but I also try to do the right thing, and that's sometimes maybe not throwing somebody out on an allotment with nothing around it when you might have something of higher value or higher risk threatened within the next 24 or 48 hours. - Protection agency interviewee

64. I think the important thing for us is to make sure we're communicating what our needs are. Not only through the agencies, our different agencies that we work with up through the [U.S.] Department [of the Interior]. But the other aspect of it is making sure that the Native Corporations are aware of what our needs are and the concerns, [and also] making the State of Alaska aware of that. And then also communicating with our national congressional offices where we have concerns, just making sure that they're aware of what our situation is as far as being able to provide the services we're supposed to. And when do we have concerns or issues, to make sure they're in the loop on that. And that generally is the best tool we can have, to try to garner additional support or resources for us to do our job. Jurisdictional agency interviewee 